\title{
Copyright ANd Time: A Proposal ${ }^{\dagger}$
}

\author{
By Joseph P. Liu ${ }^{*}$
}

\begin{abstract}
This Article argues that courts should adjust the scope of copyright protection by considering time as a factor in fair use analysis. More specifically, the longer it has been since a copyrighted work was published, the greater the scope of fair use should be. Up to now, most of the debate over the role of time in copyright law has focused on the controversial issue of copyright duration and term extension. By focusing so narrowly on the end of the copyright term, however, this debate has neglected the more significant issue of how time should affect the scope of copyright protection during the copyright term. This Article argues that exceptionally strong justifications exist for considering time expressly in setting the scope of copyright protection, and that fair use provides an ideal vehicle for such consideration, both doctrinally and theoretically. By considering time in fair use analysis, courts can adjust the scope of copyright protection to respond more dynamically to the changes that occur in authorial incentives, public access, and other copyright interests over the length of the copyright term. Consideration of time also provides a legitimate way for courts to inject public-regarding values into the process of setting the scope of copyright protection.
\end{abstract}

\footnotetext{
$\dagger$ Draft: Please do not quote or cite without permission. Please send any comments and suggestions to liujr@bc.edu.

* Assistant Professor, Boston College Law School. L.L.M. 1999, Harvard; J.D. 1994, Columbia; B.A. 1989, Yale. E-Mail: liujr@bc.edu. Thanks to Stacey Dogan, Douglas Lichtman, Mark Lemley, Michael Madison, Alfred Yen, and the participants at the Boston College Faculty Colloquium and the Northeastern Junior Faculty Exchange for helpful comments and suggestions. This Article was prepared in part with the generous support of a summer research grant from the Dr. Thomas F. Carney Gift Fund. (C) Copyright 2002 by Joseph P. Liu.
} 


\section{TABLE OF CONTENTS}

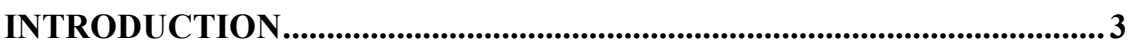

I. THE PROPOSAL IN CONTEXT .................................................................... 6

A. THE DEBATE OVER TERM EXTENSION.................................................... 6

B. INITIAL RESPONSES TO TERM EXTENSION.............................................. 14

II. THEORETICAL ARGUMENTS .............................................................20

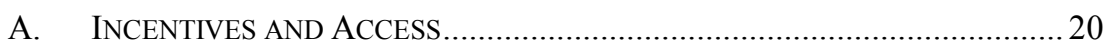

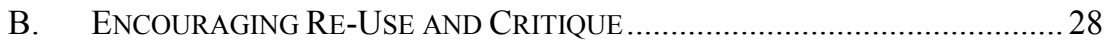

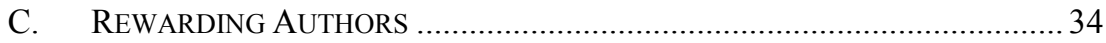

D. POLITICAL ECONOMY ARGUMENTS .................................................... 38

III. DOCTRINAL ARGUMENTS....................................................................... 43

A. Text, Legislative History, CASe LaW …………...............................4 43

B. DEALING WITH SONNY BONO.............................................................. 49

IV. THE PROPOSAL IN DETAIL ...............................................................52

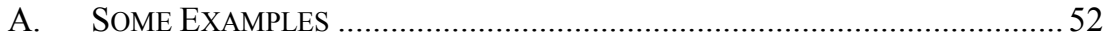

1. Transformative Uses ..................................................................... 52

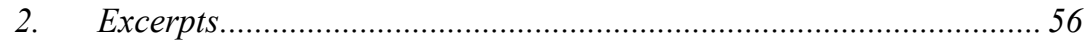

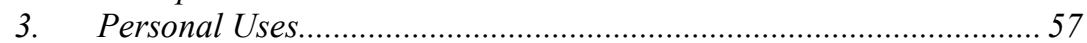

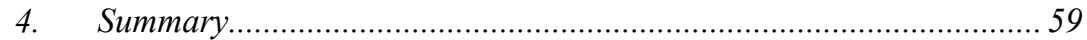

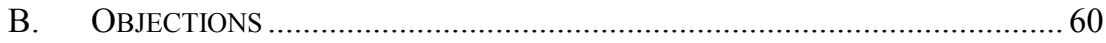

CONCLUSION.......................................................................................................6 64 


\section{INTRODUCTION}

This Article makes a very specific and concrete proposal. It argues that courts deciding copyright cases should adjust the scope of copyright protection to account for the passage of time, and that they should do so by considering time expressly as a factor in fair use analysis. ${ }^{1} \quad$ More specifically, this Article argues that the older a copyrighted work is, the greater the scope of fair use should be - i.e. the greater the ability of others to re-use, critique, transform, and adapt the copyrighted work without permission of the copyright owner. Conversely, the younger the work, the narrower the scope of fair use. Or, put even more concretely, this Article argues that fair use should be greater for Mickey Mouse ${ }^{2}$ than for Harry Potter. ${ }^{3}$

Up to now, most of the debate over the role of time in copyright law has focused on copyright duration and the controversial issue of copyright term extension. ${ }^{4}$ Since passage of the first Copyright Act, Congress has dramatically extended the copyright term from an original maximum term of 28 years to the current term of 70 years after the death of the author. ${ }^{5}$ Congress's most recent extension of the term by another 20 years in $1998^{6}$ has touched off a fierce debate over both the propriety and constitutionality of this extension. Those supporting the extension have argued, inter alia, that it encourages creative activity and is necessary to provide incentives to preserve copyrighted works in the

\footnotetext{
${ }^{1}$ See 17 U.S.C. $§ 107$ (1994).

${ }^{2}$ Mickey Mouse first appeared in 1928 in a short animated film, under the name Steamboat Willie. See Steamboat Willie (1928).

${ }^{3}$ See J.K. Rowling, Harry PotTer AND the SorCeror's Stone (1998).

${ }^{4}$ See, e.g., Eldred v. Reno, 239 F.3d 372 (D.C. Cir. 2001), cert. granted sub nom. Eldred v. Ashcroft, _ S.Ct. _ 10 U.S.L.W. 3292 (2002); Peter Jaszi, Caught in the Net of

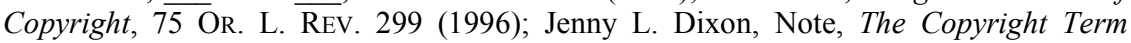
Extension Act: Is Life Plus Seventy Too Much?, 18 Hastings Comm/EnT. L.J. 945 (1996); Lisa Brownlee, Recent Changes in the Duration of Copyright in the United States and European Union: Procedure and Policy, 6 Fordham InTELl. Prop. MEDiA \& ENT. L.J. 579 (1996); Joseph A. Lavigne, Comment, For Limited Times? Making Rich Kids Richer Via the Copyright Term Extension Act of 1996, 73 U. DET. MERCY L. REV. 311 (1996); J. H. Reichman, The Duration of Copyright and the Limits of Cultural Policy, 14 CARdozo ARTs \& EnT. L.J. 625 (1996); Marci Hamilton, Copyright Duration Extension and the Dark Heart of Copyright, 14 CARDOzo ARTS \& ENT. L.J. 655 (1996); William F. Patry, The Copyright Term Extension Act of 1995: Or How Publishers Managed to Steal the Bread From Authors, 14 CARdozo ARTs \& ENT. L.J. 661 (1996); Shauna C. Bryce, Life Plus Seventy: The Extension Of Copyright Terms In The European Union And Proposed Legislation In The United States, 37 HARV. INT'L L.J. 525 (1996).

${ }^{5}$ See 1 Paul Goldstein, Copyright $\S 4.7$, at 4:138 (Supp. 2001).

${ }^{6}$ See Sonny Bono Copyright Term Extension Act, Pub. L. No. 105-298, 112 Stat. 2827, amending 17 U.S.C. § 304(b).
} 
digital age. $^{7}$ Those opposing the extension have argued that the extension provides effectively no additional incentive for creative activity ${ }^{8}$ that it harms the public by depriving it of free access to works, and that it may well be unconstitutional. ${ }^{9}$ This debate is part of a larger, ongoing debate over the proper scope of copyright protection in the digital age.

By focusing so narrowly on the end of the copyright term, however, this debate has neglected the significant issue of how time should affect the scope of copyright protection during the copyright term. ${ }^{10}$ That is, whether or not the most recent extension is justified or constitutional, the fact remains that the copyright term is currently extremely long, much longer than the drafters of the original copyright act ever contemplated. Up to now, however, courts and commentators have directed their attention at the end of the copyright term, and have largely assumed that the scope of protection during the term is constant or unaffected, at least directly, by the passage of time. Perhaps this assumption made sense when the copyright term was a short 28 years, but does it still hold now that the term of protection often spans an entire century? How, if at all, are the policies and justifications underlying copyright law affected by the passage of time, and what implications, if

\footnotetext{
${ }^{7}$ See, e.g., Senator Orrin Hatch, Toward a Principled Approach to Copyright Legislation at the Turn of the Millennium, 59 U. PITT. L. REV. 719, 736 (1998); The Honorable Howard Coble, Recent Developments in Intellectual Property, 22 Colum.-VLA J.L. \& ARTs 269, 296 (1998); Arthur Miller, Copyright Term Extension: Boon for the American Creators and the American Economy, 45 J. COPYRIGHT SOC'y 319, 325 (1997). See infra Part I.A. for a fuller articulation of these arguments.

8 See, e.g., Written Testimony of Dennis S. Karjala on behalf of Copyright and Intellectual Property Law Professors before the House Subcommittee on Courts and Intellectual Property, H.R. 989, July 13, 1995; Oral Testimony of Professor Peter Jaszi on S. 483 before the Senate Committee on the Judiciary, Sept. 20, 1995. See infra Part I.A. for a fuller articulation of these arguments.

9 See, e.g., Lawrence Lessig, Copyright's First Amendment, 48 U.C.L.A. L. REV. 1057 (2001); Neil Weinstock Netanel, Locating Copyright Within the First Amendment Skein, 54 StAN. L. REV. 1 (2001) (applying intermediate First Amendment scrutiny to term extension and finding that term extension fails); Paul Heald \& Suzanna Sherry, Implied Constitutional Limits on Congressional Power: Construing the Commerce Power in Light of the Intellectual Property Clause, 2000 U.ILL. L. REV. 1119 (concluding that the term extension likely exceeded implied limits on Congressional authority imposed by the Copyright Clause). For a more comprehensive list of articles on the constitutionality of the term extension, see infra note 74.

${ }^{10}$ A notable exception is Note, Gone With the Wind Done Gone: "Re-Writing" and Fair Use, 115 HARV. L. REV. 1193 (2002), which addresses the issue of time, though not in the context of copyright duration. The Note instead argues, more narrowly, that courts should consider time in fair use cases involving an author's re-writing or adaptation of a prior literary work.
} 
any, are there for the appropriate scope of copyright protection? Up to now, these questions have been left largely unaddressed. ${ }^{11}$

In this Article, I will argue that extremely strong justifications exist for considering time expressly in setting the scope of copyright protection, and that fair use provides an ideal vehicle for such consideration, both doctrinally and theoretically. Indeed, an examination of the theoretical justifications underlying copyright law reveals that the strength and impact of these justifications are quite directly affected by the passage of time. Over the course of the copyright term, for example, the impact of protection on copyright incentives wanes, as does an author's moral claim to the fruits of his or her labor. At the same time, the societal interest in ensuring widespread access to works and in encouraging re-use and adaptation of copyrighted works increases. By considering time in fair use analysis, courts can thus adjust the scope of copyright protection to respond more dynamically to the changes in these and other copyright interests over the length of the copyright term. ${ }^{12}$

Furthermore, such a result could, unlike recent constitutional challenges to term extension, be achieved quite easily within existing copyright case law and would not require courts to stretch the doctrine or strike down any statutes. Indeed, existing fair use doctrine provides ample support for consideration of time as a factor in fair use analysis. Specifically, the Copyright Act and its legislative history expressly authorize courts to consider additional factors in fair use analysis, and courts have used this authorization to consider a wide range of additional factors not expressly mentioned in the statute. ${ }^{13}$ Given the strong theoretical arguments for considering time, courts should feel quite comfortable considering time as an additional factor in fair use analysis. Thus, consideration of time in fair use analysis would be a modest doctrinal change that could have significant beneficial effects on the scope of copyright protection.

Finally, the proposal advanced in this Article would also have the beneficial effect of providing courts with a legitimate way of injecting much-needed public-regarding values into the scope of copyright protection. One of the concerns underlying the debate over copyright term extension has been the extent to which the extension, and all of the prior extensions, result from a structural imbalance in lobbying power. ${ }^{14}$ Because the benefits of term extension accrue to a few, highlyfocused and well-organized interests, and the costs of extension, though

\footnotetext{
${ }^{11}$ But see, id.

${ }^{12}$ Compare Note, supra note 10 (advancing a narrower argument involving time and fair use).

${ }^{13}$ See infra Part III.A.

${ }^{14}$ See infra Part II.D.
} 
significant in the aggregate, are more widely distributed among the population at large, calls for term extension are difficult to oppose, as public choice theory predicts. Indeed, this imbalance has been reflected not only in the struggle over term extension, but also in other Congressional expansions of copyright protection. For those concerned about this structural imbalance, the proposal in this Article provides a mechanism for courts to legitimately incorporate public-regarding values into the scope of copyright protection. ${ }^{15}$ Even for those who are not concerned, however, the policy justifications are more than sufficient to support the proposal.

The rest of this Article seeks to explain the proposal in more detail and build the case in support of it. Part I of this Article provides the context for the proposal, describing the debate over term extension and the arguments on both sides of the issue. It then sketches out the proposal very briefly and explains how the proposal relates to this wider debate. Part II then examines the theoretical argument in support of the proposal, concluding that the proposal finds extremely strong support under several different theories underlying copyright law more generally. I start with the policy arguments, rather than the doctrine, because these arguments provide the impetus for the proposal. Part III then builds the doctrinal case for the proposal, examining the doctrine, case law, and legislative history for support. The conclusion I reach is that the copyright act clearly authorizes courts to consider time in their fair use analysis, and that, given the strong policy reasons supporting such a consideration, they should do so. Part IV then returns to the proposal and fleshes it out by applying it to a number of concrete examples and showing how the proposal would have many concrete benefits. Part IV then concludes by addressing a number of anticipated objections.

\section{THE PROPOSAL IN CONTEXT}

\section{A. THE DEBATE OVER TERM EXTENSION}

Over the next 16 years, not a single published copyrighted work in the United States will pass into the public domain. ${ }^{16}$ That is, from now until December 31, 2018, not a single published copyrighted work

15 See Maureen O'Rourke, Essay, Evaluating Mistakes in Intellectual Property Law: Configuring the System to Account for Imperfection, 4 J. SMAll \& EMERGING Bus. L. J. 167 (2000) (arguing that courts interpreting intellectual property statutes can play a role in compensating for imperfections in the legislative process).

${ }^{16}$ The precise date is Dec. 31, 2018, for a work copyrighted in 1923. The Copyright Act provides that works whose terms would technically expire during the year retain copyrighted status until the end of that calendar year. 17 U.S.C. $\S 305$. 
will have its term of copyright protection expire. ${ }^{17}$ This is because Congress in 1998 passed the Sonny Bono Copyright Term Extension $\mathrm{Act}^{18}$, which extended the term of copyright protection by an additional 20 years. For works authored by individuals, this means that the term now extends until 70 years after the death of the author; for works authored by corporate entities, ${ }^{19}$ this means that the term is now 95 years from the date of publication or 120 years after creation, whichever expires first. Congress also made this extension retroactive, applying it not only to future works, but also to any already-existing works that were still under copyright at the time the extension went into effect. The result of the retroactive application of the extension was that no more works would pass into the public domain for a 20 year period after the Act went into effect.

The practical impact of this extension on copyright markets is significant. Until passage of the extension, copyrighted works had been passing into the public domain at a steady pace. In 1998, for example, T.S. Eliot's "The Waste Land," James Joyce's "Ulysses, ${ }^{20 "}$ and the movie "Blood and Sand" with Rudolph Valentino all passed into the public domain. ${ }^{21}$ The previous year, in 1997, F. Scott Fitzgerald's "This Side of Paradise," D.H. Lawrence's "Women in Love," Edith Wharton's "The Age of Innocence," and the song "Over There" by George M. Cohan all passed into the public domain. ${ }^{22}$ What this meant was that these works could now be freely copied, distributed, and built upon by others. So if you wanted to print and sell copies of "The Waste Land," you could freely do so without seeking a license from, or paying a royalty to, the copyright owner. Similarly, if you wanted to write and sell your own sequel of "This Side of Paradise," or make a movie out of

\footnotetext{
${ }^{17}$ Note the qualification "published." Certain previously unpublished works, which were brought under copyright protection under $\$ 303$ of the 1976 Act, will enter the public domain on Jan. 1, 2003, unless they are published before that date, in which case they will be protected until 2047. 17 U.S.C. $\$ 303$.

${ }_{11}^{18}$ Pub. L. No. 105-298, 112 Stat. 2827, amending 17 U.S.C. § 304(b).

19 Or, more precisely, works "made for hire." 17 U.S.C. § 302(c). Anonymous and pseudonymous works also share this same term. Id.

${ }^{20}$ But see Robert Spoo, Note, Copyright Protectionism and its Discontents: The Case of James Joyce's Ulysses in America, 108 YALE L.J. 633 (1998) (suggesting that Ulysses in fact passed into the public domain long ago as a result of failure to comply with certain requirements).

${ }^{21}$ These examples and many others can be found at Dennis Karjala's wonderful web site, Opposing Copyright Extension $<$ http://www.law.asu.edu/HomePages/Karjala/OpposingCopyrightExtension/> ～(visited July 31,2001$)$.

${ }^{22}$ See id.
} 
"The Age of Innocence", you could do so. All of these uses were now freely permitted, once the term of copyright protection ended. ${ }^{23}$

The fact that these works passed into the public domain was no accident. Rather, it was an essential part of the design of copyright law. ${ }^{24}$ The basic idea behind copyright law is that an author gets a certain number of years during which he or she can prevent unauthorized copying and distribution of the creative work. This exclusive period permits the copyright owner to exploit the work and obtain a return for his or her creative labor, thus providing an incentive to engage in the labor in the first place. This period is limited, however. The Constitution itself expressly authorizes copyright protection only for "limited Times," 25 and the Copyright Act places precisely such a limit on the duration of copyright. ${ }^{26}$ The idea behind the limited grant is that, after an author has been sufficiently compensated ${ }^{27}$ for his or her creative labor, the work should pass into the public domain so that all of society can use it freely, so that it can be disseminated more broadly, so that its ideas can be appropriated and built upon. ${ }^{28}$ This reflects the balance struck by copyright law between providing incentives for creation and promoting wide dissemination for the fruits of the creation.

Because of the passage of the Sonny Bono Copyright Term Extension Act, ${ }^{29}$ however, many copyrighted works that were scheduled to pass into the public domain in the years from 1998 through 2018 will

${ }^{23}$ See also E. Scott Johnson, Law Gives Copyrights New Life, NAT'L L.J., Feb. 8, 1999, at $\mathrm{C} 12$ (listing works that would have gone into the public domain, but for the extension); Richard Epstein, Congress's Copyright Giveaway, Wall ST. J., Dec. 32, 2998, at A19.

${ }^{24}$ See, e.g., Stewart v. Abend, 495 U.S. 207, 288 (1990) ("The copyright term is limited so that the public will not be permanently deprived of the fruits of an artist's labors."); Sony Corp. of Am. v. Universal City Studios, 464 U.S. 417, 429 (1984) (copyright "is intended to motivate the creative activity of authors and inventors by the provision of a special reward, and to allow the public access to the products of their genius after the limited period of exclusive control has expired.”); Jessica Litman, The Public Domain, 39 Emory L.J. 965 (1990); David Lange, Recognizing the Public Domain, 44 LAw \& CONTEMP. Probs., Autumn 1981, at 147, 171..

${ }^{25}$ U.S. ConST. Art. I, $\S 8$. "To promote the Progress of Science and useful Arts, by securing for limited Times to Authors and Inventors the exclusive Right to their respective Writings and Discoveries." See Melville Nimmer, Does Copyright Abridge the First Amendment Guarantees of Free Speech and Press?, 17 UCLA L. REV. 1180, 1193 (1970).

${ }^{26} 17$ U.S.C. $\$ 304(b)$.

${ }^{27}$ Not surprisingly, there is much difference of opinion over what is "sufficient". See infra Part II.A.

28 See David Nimmer, The End of Copyright, 48 VAND. L. REv. 1385, 1416 (1995) (" $[\mathrm{W}]$ orks are relegated to the public domain to become the heritage of all humanity and copyright is simply a temporary way station to reward authors on the road to that greater good."); Litman, Public Domain, supra note 24.

${ }^{29}$ See generally, Jane Ginsburg, Copyright Legislation for the "Digital Millennium”, 23 COLum.-VLA J.L. \& ARTS 137, 170 (1999). 
now remain copyrighted for an additional 20 years. Among these works are Disney's copyrights in the original Mickey Mouse ${ }^{30}$ (originally scheduled to expire in 2003), ${ }^{31}$ the Gershwin family's copyright in George Gershwin's "Rhapsody in Blue" (originally scheduled to expire in 1999), ${ }^{32}$ numerous works by Cole Porter, Irving Berlin, Hoagy Carmichael, Ernest Hemingway and William Faulkner, ${ }^{33}$ as well as thousands of other books, articles, movies, songs, photographs, and artworks from the artistically productive decades of the $1920 \mathrm{~s}$ and $30 \mathrm{~s}^{34}$ The owners of these copyrights will now be able to license and receive revenue from those copyrights for an additional 20 years. The public, conversely, will now have to wait an additional 20 years for these works, as well as all of the other works still under copyright at the time of the extension, to pass into the public domain.

This extension was merely the latest in a long line of congressional extensions of the copyright term, which have had the effect of dramatically extending the term of copyright protection beyond what the Framers of the Constitution originally contemplated. The term of protection under the original 1790 Act was for 14 years, with the possibility of renewal for another 14 year term, resulting in a potential total of 28 years. $^{35}$ The maximum possible term was lengthened in 1831 to 42 years $^{36}$, then in 1909 to 56 years $^{37}$. And then, beginning in 1962, Congress embarked on a steady course of incremental extensions (9

${ }^{30}$ See Steamboat Willie (1928). Pluto would have gone into the public domain in 2006, and Goofy in 2008. Similarly, the copyright in A.A. Milne's Winnie the Pooh, which Disney had just recently acquired, was also scheduled to fall into the public domain. See Jon Garon, Media \& Monopoly in the Information Age: Slowing the Convergence at the Marketplace of Ideas, 17 CARDOZO ARTS \& ENT. L.J. 491, 523 (1999); Hannibal Travis, Comment, Pirates of the Information Infrastructure: Blackstonian Copyright and the First Amendment, 15 BERKELEY TECH. L.J. 777, 828 (2000).

${ }^{31}$ See Disney Lobbying for Copyright Extension No Mickey Mouse Effort, Chi. Trib., Oct. 17, 1998, at 22.

32 See Dennis Karjala, Value of the Public Domain, $<$ http://www.law.asu.edu/HomePages/Karjala/OpposingCopyrightExtension/publicdomai n/Pdlist.html $>$ (visited July 31, 2001).

33 See Teresa Ou, From Wheaton v. Peters to Eldred v. Reno: An Originalist Interpretation of the Copyright Clause $<\mathrm{http}: / /$ cyber.law.harvard.edu/eldredvreno/legal.html $>$.

${ }^{34}$ See Carl S. Kaplan, Free Book Sites Hurt by Copyright Law, N.Y. TIMES ON THE WEB, $\quad$ Oct. 30,1998 $<$ http://www.nytimes.com/library/tech/98/10/cyber/cyberlaw/30law.html> (quoting Michael Hart, director of the Gutenberg Project, estimating that the extension "will essentially prevent about one million books from entering the public domain over the next 20 years.")

${ }^{35}$ See Goldstein, supra note 5, at $\S 4.7$, at 4:138; Copyright Act of 1790, § 1, 1 Stat. 124 (1790).

${ }^{36}$ See Act of Feb. 3, 1831, §§ 1-2, 4 Stat. 436.

${ }^{37}$ See Copyright Act of 1909, 17 U.S.C. § 23 (1909) (repealed 1978). 
separate times within 12 years $)^{38}$, which expanded the maximum term from 56 to 70 years for subsisting works. ${ }^{39}$ In the substantial 1976 revision of the Act, Congress extended the maximum possible term for existing works to 75 years, and for future works, replaced the prior fixed term from publication with a term based on the life of the author, plus 50 years. ${ }^{40}$ This change in the calculation of the term resulted in a dramatic extension of the copyright term. ${ }^{41}$ Thus, for works created after 1976, the copyright term could potentially be much longer than 75 years. (For example, a work created in an author's 30 s could have a copyright term of more than 90 years from publication, if the author lives to at least 70). Finally, the latest extension occurred in 1998, with passage of the Bono Act. $^{42}$

Many of these extensions (and proposals for extensions) ${ }^{43}$ came under heavy attack from various academics and public interest groups, ${ }^{44}$ and the Bono Act was no exception. ${ }^{45}$ With respect to the extension for future works, commentators pointed out that any additional revenue created by an additional 20 years of protection more than 50 years after

${ }^{38}$ Pub. L. 87-668 (1962) (59 years); Pub. L. 89-142 (1965) (61 years); Pub. L. 90-141 (1967) (62 years); Pub. L. 90-416 (1968) (63 years); Pub. L. 91-147 (1969) (64 years); Pub. L. 91-555 (1970) (65 years); Pub. L. 92-170 (1971) (66 years); Pub. L. 92-566 (1972) (68 years); Pub. L. 93-573 (1974) (70 years).

${ }^{39}$ These extensions were made in anticipation of the substantial 1976 revision of the Act.

${ }^{40}$ Pub. L. 94-553 (1976) (75 years), codified at 17 U.S.C. $\$ 304$.

${ }^{41}$ See generally Tom Bell, Escape From Copyright: Market Success v. Statutory Failure in the Protection of Expressive Works, 69 U. Cin. L. Rev. 741, 781 (2001).

${ }^{42}$ Pub. L. No. 105-298, 112 Stat. 2827, amending 17 U.S.C. § 304(b).

${ }^{43}$ Many of the arguments made both in support of, and against, the Sony Bono Copyright Term Extension Act were made a few years earlier, in the debate over the proposed 1995 Copyright Term Extension Act, which was not enacted. See The Copyright Term Extension Act, Hearings on S. 483 Before the Senate Judiciary Comm., 104th Cong., 1st Sess. (1995); Hearings on H.R. 989 Before the Subcomm. on Courts and Intellectual Property of the House Comm. on the Judiciary, 104th Cong., 1st Sess. (1995); Jaszi, supra note 4; Dixon, supra note 4; Brownlee, supra note 4; Lavigne, supra note 4; Reichman, supra note 4; Hamilton, supra note 4; Patry, supra note 4; Bryce, supra note 4. Because the two acts are so close in time and involved essentially the same arguments and opposing parties, I will treat arguments raised in both instances largely interchangeably.

${ }^{44}$ See Stephen Breyer, The Uneasy Case for Copyright: A Study of Copyright in Books, Photocopies, and Computer Programs, 84 HARV. L. ReV. 281, 323 (1970) (detailing the doubtful case for extension of the pre-1976 Act term); Ralph S. Brown, Copyright and Its Upstart Cousins: Privacy, Publicity, Unfair Competition, 33 J. COPYRIGHT SOC'Y U.S.A. 301, 302 (1986).

${ }^{45}$ See generally Karjala, supra note 21 (collecting materials submitted in opposition to term extension); Dennis Karjala, Statement of Copyright and Intellectual Property Law Professors in Opposition to H.R. 604, H.R. 2589, and S. 505, Submitted to the Committees on the Judiciary, U.S. Senate and U.S. House of Representatives (Jan. 28, 1998); Christina Gifford, Note, The Sonny Bono Copyright Term Extension Act, 30 U. Mem. L. Rev. 363 (2000); Bell, supra note 30. 
the death of the author was unlikely to lead to any appreciable increase in creative effort or activity, given the long period of time over which any revenues would have to be discounted. ${ }^{46}$ And even if one conceded some minimal degree of incentive for future works, such an added incentive could not be used to justify extension of the term to works that had already been created. That is, the works have already been created, so how would extending protection increase the incentives to create them? ${ }^{47}$ At the same time, opponents of term extension argued, the extension imposes substantial costs on the public, by depriving it of free access to copyrighted works. That is, the public must now wait another 20 years before obtaining such access, even for works that had already been created under the prior term. ${ }^{48}$ In addition, authors who wish to use such works as the basis for new creative works must seek permission and license such uses from the copyright owners for an additional 20 years. ${ }^{49}$ Thus, to many opponents of term extension, the Act represented little more than a transfer of wealth from the public to existing copyright owners. ${ }^{50}$

Despite these arguments against term extension, Congress went ahead and extended the term, making it also retroactive. In support of extension, Congress offered additional reasons on top of incentive rationale set forth above. ${ }^{51}$ One justification was based on the argument that incentives were needed to convert non-digital works into digital form and to preserve such digital copies, in light of the fragile nature of such copies. Another justification was based on the need to maintain a positive trade surplus by harmonizing the copyright term with the terms of European countries. ${ }^{52}$ The European Community had instituted a rule

\footnotetext{
${ }^{46}$ See Karjala, Statement, supra note 45.

47 See, e.g., James Boyle, Cruel, Mean or Lavish? Economic Analysis, Price Discrimination and Digital Intellectual Property, 53 VAND. L. REV. 2007, 2036 (2000) ("Can you really explain the Sonny Bono Copyright Term Extension Act economically, perhaps as an attempt to offer incentives to the dead?"); Ginsburg, supra note 29 ("[I]t is important to emphasize that the traditional justification of copyright protection, as an incentive to the creation of works of authorship, simply does not apply to extension of the term of pre-existing works."); Travis, supra note 30, at 817-18. But see Hatch, supra note 7 , at 736 (arguing that incentive impact results from the fact that existing authors, by receiving more revenue, are free to engage in other creative activities).

${ }^{48}$ See Karjala, Statement, supra note 45.

49 See Ginsburg, supra note 29, at 171 (retroactive extension "cannot enhance the quantum of creativity from the past, but it can compromise the creativity of the future, by delaying for twenty years the time at which subsequent authors may freely build on these works").

${ }^{50}$ See Patry, supra note 4 (criticizing earlier bills that would have extended the term).

${ }^{51}$ See generally Hatch, supra note 7, at 728; Coble, supra note 7, at 296; Miller, supra note 7 , at 325 .

52 See Cong. Rec. S11, 672-674, S11, 794-796, H9949-54 (daily ed. Oct. 7, 1998); Cong. ReC. H9950 (daily ed. Oct. 7, 1998); Jane Ginsburg, et al., Symposium, The
} 
that provided foreign works protection for the shorter of the EC term or the domestic term for the foreign country. Since the term for many works in European countries is life plus seventy years, many U.S. works under the old term would obtain twenty years less protection in Europe. U.S. companies would thus, the argument went, be operating under a disadvantage, and this would have an unfavorable impact on our balance of trade, since the U.S. is a net exporter of copyrighted works. ${ }^{53}$

As other commentators have demonstrated, however, these additional justifications for term extension were rather weak. There was no indication or evidence that the existing term was insufficient to provide the incentives needed to digitize and preserve copyrighted works, or that extending protection would increase such incentives. ${ }^{54}$ Moreover, the goal of harmonizing protection with the EC is largely an illusory one. As an initial matter, harmonization in the abstract is not a satisfactory reason in and of itself, without some understanding of the costs and benefits of harmonization, particularly given that U.S. copyright law and European copyright law are based on two very different theoretical models. ${ }^{55}$ Moreover, the extension would not in fact

Constitutionality of Copyright Term Extension: How Long is Too Long?, 18 CARdOzO ARTS \& ENT. L.J. 651, 690, 700 (2000) (statements by Arthur Miller and Jane Ginsburg); Ginsburg, supra note 29, at 171; Hatch, supra note 7, at 728-30; The Copyright Term Extension Act of 1995: Hearing on S. 483 Before the Senate Comm. on the Judiciary, 104th Cong. 20, 23 (1995) (statement of Marybeth Peters, Register of Copyright).

${ }^{53}$ Proponents of the extension also argued that the extension was warranted due to the desire to provide a return for an author's descendants and increasing life expectancy. See Hatch, supra note 7, at 732. But see Patry, supra note 4, at 931 (arguing that this argument is "internally contradictory. While it is true that a longer lifespan means that grandchildren of the author will live longer, it also means that the author will live longer and, therefore, will be able to provide for his or her grandchildren for an equally longer period.").

${ }^{54}$ See Travis, supra note 30, at 830 ("The wide availability of the works of Shakespeare demonstrates that public domain works need into fall into obscurity."). Indeed, the continued protection of works that would otherwise fall into the public domain may in fact lead to less preservation of works. See Mark Lemley, Brief of Amici Curiae The Internet Archive Filed on Behalf of Petitioners in Eldred v. Ashcroft (amicus brief in support of cert. pet. in $<$ http://eon.law.harvard.edu/openlaw/eldredvashcroft/cert/archive-amicus.html > (visited February 20, 2002) (arguing that extension will in fact prevent attempts to digitally preserve certain older, copyrighted works).

${ }^{55}$ See Kenneth D. Crews, Harmonization and the Goals of Copyright: Property Rights or Cultural Progress?, 6 Ind. J. Global Legal Stud. 117, 135-38 (1998) (critically analyzing congressional reliance on harmonization as a rationale for changes to the copyright act); Patry, supra note 4, at 930 (arguing that harmonzation-based arguments for term extension are "entirely post hoc"); Jerome Epping, Jr., Comment, Harmonizing the United States and European Community Copyright Terms: Needed Adjustment or Money for Nothing?, 65 U. CIN. L. REV. 183 (1996) (analyzing the extent to which term extension would in fact harmonize protection); Jaszi, supra note 4, at 304 (1996); 
have the effect of truly harmonizing protection, since other term ${ }^{56}$ and non-term features of their copyright protection regimes result in substantial differences in the treatment of copyrighted works, differences that greatly outweigh the impact of the copyright term. ${ }^{57}$ Finally, even if the Act did harmonize the scope of protection, there is no evidence that lack of harmonization would have any impact whatsoever on the U.S. trade balance.

Indeed, the best explanation for the Bono Act (and prior term extensions) is that it was motivated in large part by the lobbying efforts of the copyright industries (e.g. film, music, publishing, software, etc.), which had much to gain from an extension (particularly a retroactive one). Companies, such as Disney, with valuable copyrights that were slated to expire within the next 20 years, lobbied aggressively for the extension. ${ }^{58}$ These companies had much to gain from retroactive extension of their copyrights, since extension permitted them to protect and exploit their copyrights for an additional 20 years. At the same time, the public interest groups and commentators who opposed the extension had no similar lobbying power. And certainly the public at large was not sufficiently exercised about a topic as abstract as copyright term extension to exert any meaningful pressure on Congress to resist industry calls for extension. Thus it is perhaps not surprising that the extension was passed, despite the lack of strong policy justifications in its support.

In fact, the extension of the copyright term fits with a broader and related trend toward expanding intellectual property protection more generally. ${ }^{59}$ As many commentators have noted, in virtually every area of intellectual property, both Congress and the courts have been expanding the scope of existing intellectual property law. ${ }^{60}$ In the copyright context, Congress has extended the term and also enacted new statutes which give copyright owners increased ability to protect their

Reichman, supra note 4, at 626, 639 (arguing that the proposed 1995 extension "cannot be justified in terms of a drive for harmonization as such").

${ }^{56}$ Indeed, for certain categories of works such as sound recordings, the extended U.S. term would provide more protection than that given to similar works in Europe. See, e.g. Patry, supra note 4, at 930.

${ }^{57}$ See Karjala, supra note 8. Netanel, supra note 9, at 74-75. See also Ginsburg, supra note 29 , at $172-73$.

${ }^{58}$ See Robert Merges, One Hundred Years of Solicitude: Intellectual Property Law, 88 CALIF. L. Rev. 2187, 2236-37 (2000) (noting that the copyright term extension "was the Walt Disney Company's 'highest priority' in the 1998 legislative session of Congress.”); Robert Merges \& Glenn Reynolds, The Proper Scope of the Copyright and Patent Power, 37 HARV. J. ON LEGIS. 45 (2000); Garon, supra note 30, at 523.

59 See, e.g., Lawrence Lessig, The Future OF IDEAS (2001); Neil Weinstock Netanel, Copyright and a Democratic Civil Society, 106 YALE L.J. 283, 292 (1996) (describing such expansion); Yochai Benkler, Siren Songs and Amish Children: Autonomy, Information, and Law, 76 N.Y.U. L. REV. 23, 112-13 (2001).

${ }^{60} \mathrm{See}$, e.g., id. 
rights through technology. ${ }^{61}$ In the patent field, the scope of patentable subject matter has been extended to things previously thought unpatentable, such as business methods. ${ }^{62}$ In the trademark field, Congress has expanded protection beyond the original consumer protection rationale to recognize more property-like rights in trademarks. $^{63}$ This expansion is, in some ways, unsurprising: as more and more of the economy is based on information goods, the owners of such goods will seek to increase the protection offered to such goods. However, many commentators have become increasingly concerned about the expansion of I.P. rights and the largely ignored costs of such expansion.

\section{B. INITIAL RESPONSES TO TERM EXTENSION}

Concerned about ill effects of copyright term extension and Congress's apparent unwillingness to rein in copyright industry calls for expansion, a number of parties challenged the constitutionality of the extension in a case titled Eldred v. Reno (since re-titled Eldred v. Ashcroft). ${ }^{64}$ Eldred v. Reno was a declaratory judgment action brought by a number of plaintiffs who relied upon works in the public domain. For example, the lead plaintiff, Eric Eldred, electronically published literary works that had passed into the public domain. ${ }^{65} \mathrm{He}$ and a number of similarly-situated plaintiffs brought suit to strike down both the prospective and retroactive portions of the Act, arguing, among other things, that Congress had exceeded the scope of the grant in the Constitution's Copyright Clause. Specifically, the plaintiffs argued that the retroactive application of the extension did not "promote the progress of science and the useful arts", since there could be no justification for trying to increase incentives for existing works, and that it also violated the "limited times" language of the copyright clause. ${ }^{66}$ Plaintiffs also argued that the term extension violated the First Amendment. ${ }^{67}$

The plaintiffs lost both before the U.S. District Court ${ }^{68}$ and the U.S. Court of Appeals for the D.C. Circuit. ${ }^{69}$ In the majority opinion, the

${ }^{61}$ See, e.g., The Digital Millennium Copyright Act of 1998, codified at 17. U.S.C. $\S \S$ 1201 , et seq.

${ }^{62}$ See, e.g., State Street Bank \& Trust v. Signature Financial Serv., 149 F.3d 1368 (Fed. Cir. 1998); AT\&T v. Excel Communications, 172 F.3d 1352 (Fed. Cir. 1999).

${ }^{63}$ See, e.g., 15 U.S.C. $\$ 1125(\mathrm{c})$.

${ }^{64}$ Eldred v. Reno, 74 F. Supp. 2d 1 (D.D.C. 1999).

${ }^{65}$ See id.

${ }^{66}$ See id. The plaintiffs also argued that retroactive extension violated the Copyright Clause's originality requirement. $I d$.

${ }^{67} \mathrm{Id}$.

${ }^{68}$ See id..

${ }^{69}$ Eldred v. Reno, 239 F.3d 372 (D.C. Cir. 2001). 
Court of Appeals rejected the argument that Congress had exceeded the scope of the Constitution's Copyright Clause by extending the term retroactively. The Court reached this result by refusing to construe the preamble of the Copyright Clause ("To Promote the Progress of Science and the Useful Arts") as a substantive limitation on Congress's power. Moreover, even if the preamble were a substantive limit, the court said it had to defer to Congress's judgment, and the government's proffered justifications (i.e. a need to provide incentives to preserve existing works, the need to harmonize the U.S. copyright term with European terms, the need to preserve the U.S.'s balance of trade) were sufficient to "promote progress." The Court further rejected additional arguments based on the First Amendment, holding that copyright law's idea/expression dichotomy and fair use defense were sufficient to protect any First Amendment interests implicated by the extension. In dissent, Judge Sentelle argued that, in extending the term for existing works, Congress exceeded the scope of its authority under the Copyright Clause in that the extension did not "promote the progress of science and the useful arts," ${ }^{70}$ and in that the continual practice of congressional extensions violated the "limited times" language of the clause. The D.C. Circuit then denied a petition for rehearing en $\operatorname{banc}^{71}$ (over a dissent ${ }^{72}$ ), and the plaintiffs filed a petition for certiorari to the Supreme Court, which the Court granted. ${ }^{73}$ The case will be heard by the Supreme Court in the term.

The arguments raised in Eldred reflected similar arguments found in the academic literature. ${ }^{74}$ Indeed, the copyright term extension,

\footnotetext{
${ }^{70}$ See id., at 382 (Sentelle, J., dissenting) ("The government has offered no tenable theory as to how retrospective extension can promote the useful arts.").

${ }^{71}$ See Eldred v. Ashcroft, 255 F.3d 849 (D.C. Cir. 2001)

${ }^{72}$ See id., at 852 (Sentelle, J., dissenting) ("Once a work is published, however, extending the copyright term does absolutely nothing to induce further creative activity by the author - how could it? The work is already published."), cert. granted, S.Ct. , 10 U.S.L.W. 3292 (2002)

${ }^{73}$ Eldred v. Ashcroft, $\quad$ S.Ct. _ 10 U.S.L.W. 3292 (2002).

${ }^{74}$ See, e.g., Lessig, supra note 9; Netanel, supra note 9 (applying intermediate First Amendment scrutiny to term extension and finding that term extension fails); Heald \& Sherry, supra note 9 (concluding that the term extension likely exceeded implied limits on Congressional authority imposed by the Copyright Clause); Benkler, supra note 59; L. Ray Patterson, Understanding the Copyright Clause, 47 J. COPYRIGHT SOC'Y U.S.A. 365 (2000); Mark Lemley, The Constitutionalization of Technology Law, 15 BERKELEY TECH. L.J. 529 n. 9 (2000) (listing articles); Edward Walterscheid, Defining the Patent and Copyright Term: Term Limits and the Intellectual Property Clause, 7 J. INTELL. PROP. L. 315 (2000) (charting the history behind the Intellectual Property clause); Michael Davis, Extending Copyright and the Constitution: "Have I Stayed Too Long?", 52 Fla. L. Rev. 989 (2000); Alfred Yen, A First Amendment Perspective on the Idea/Expression Dichotomy and Copyright in a Work's "Total Concept and Feel," 38 EMORY L.J. 393 (1989); L. Ray Patterson, Free Speech, Copyright, and Fair Use, 40 VAND. L. Rev. 1 (1987); Floyd Abrams, First Amendment and Copyright, 35 J. CopR. SOC'Y 1 (1987);
} 
along with a number of other recent legislative expansions of copyright protection, have spawned a rich literature examining the potential limits on Congress's power to expand copyright protection. Some commentators have argued that recent Congressional expansions, particularly the retroactive extension of the copyright term, violate internal limits imposed by the Constitution's intellectual property clause, notably the requirement that copyright legislation "promote the progress of science and the useful arts". ${ }^{75}$ Others have argued that such expansions may violate external limits imposed by the First Amendment. ${ }^{76}$ In all, a generous amount of scholarship has been produced analyzing the term extension, most of it concluding that the extension, at least the retroactive aspect of it, is constitutionally problematic.

Thus far, however, the judicial response to these arguments has not been favorable. ${ }^{77}$ True, the Supreme Court has granted certiorari in Eldred and could ultimately reverse, or another circuit court presented with the same challenge could reach a different conclusion. (Indeed, another case has been filed in another circuit, with similar facts). ${ }^{78}$ And the arguments against retroactive extension of the copyright term are certainly strong enough to warrant such a result. At the same time, the fact remains that courts have not generally been sympathetic to such arguments thus far. Furthermore, even if the Supreme Court were to strike down the retroactive extension, there still remains the problem of prospective extension of the Copyright term, and the arguments against prospective extension are weaker. The courts will be exceptionally deferential to Congress's judgments about the proper term length, and rightly so, since the length of the term is, to some extent, arbitrary. Finally, even if the Court did strike down both the retrospective and prospective aspects of the term extension, it would still leave intact the pre-existing term of copyright protection, which was already extremely long. ${ }^{79}$ Thus, regardless of how the courts ultimately decide the

Robert Denicola, Copyright and Free Speech: Constitutional Limitations on Protection of Expression, 67 CaL. L. Rev. 283 (1979); Paul Goldstein, Copyright and the First Amendment, 70 Colum. L. Rev. 983 (1970); Melville B. Nimmer, Does Copyright Abridge the First Amendment Guarantees of Free Speech and Press?, 17 UCLA L. REV. 1180 (1970); Merges \& Reynolds, supra note 58; Ginsburg, et. al., supra note 52.

${ }^{75}$ See, e.g., Heald \& Sherry, supra note 9; Patterson, Understanding, supra note 74; Walterscheid, supra note 74.

${ }^{76}$ See, e.g., Lessig, supra note 9; Benkler, supra note 59; Netanel, supra note 9.

77 See Eldred v. Reno, 239 F.3d 372 (D.C. Cir. 2001); see also Universal City Studios v. Corley, 273 F.3d 429 (2d Cir. 2001).

${ }^{78}$ See Golan v. Ashcroft, Civ. No. 01-B-1854 (D. Colo. 2001).

79 The incentive to lobby for future prospective extensions may well be eliminated if retroactive extensions are found to be unconstitutional, since those lobbying for such extensions are primarily concerned with gaining additional protection for existing 
constitutional issue, we will still be left with an extremely long copyright term.

\section{The Proposal - An Overview}

Given that direct constitutional challenges to term extension do not appear to fully address the issues raised by term extension, and given that political pressure through the elected branches is more likely to result in a longer (rather than shorter) copyright term, are there any other means within existing doctrine to somehow reduce the ill-effects of the term extension? That is, are there less dramatic ways to permit courts, within the existing structure and doctrine of copyright law and short of striking the extension down, to incorporate some of the justifiable concerns raised by the opponents of term extension? I believe that the answer is yes. Indeed, I believe that existing copyright law doctrines provide courts with the tools not only to mitigate some of the ill-effects of the recent term extension, but, more broadly, to arrive at a much more well-balanced and finely-tuned consideration of copyright scope, one that, for the first time, recognizes and takes account of the vast expansion of the copyright term and its impact on the policies underlying copyright law. Which leads me to my proposal.

The proposal is simple: in deciding whether a given use of a copyrighted work is fair use ${ }^{80}$ courts should take into account how long it has been since the work was published. ${ }^{81}$ Thus, the more recent the work, all other things being equal, the narrower the scope of fair use; the older the work, the greater the scope of fair use. So, for example, a book written 70 years ago should be subject to a greater degree of fair use. The ability to make sequels, to copy portions of it, to comment upon it, to transform and re-work it, should, all other things being equal, be greater than the similar ability to make fair use of a book written only 2 years ago. Conversely, a book written just 2 years ago should be subject to a much narrower scope of fair use. Or, put even more concretely, fair use should be greater for Mickey Mouse than for Harry Potter. ${ }^{82}$

copyrighted works (and the benefits from future extensions are so attenuated, as discussed in more detail below in Part II.A.). This is one of the tactical reasons supporting the retroactive attack in particular. However, this would not address the current prospective extension nor, more generally, the already-too-long copyright term. ${ }^{80} 17$ U.S.C. $\S 107$.

${ }^{81}$ See also Note, supra note 10, at 1209 (proposing that courts consider both time and the size of the author's reward in deciding whether the re-writing of another author's literary work constitutes fair use).

82 For purposes of simplification, I refer here, and elsewhere, to the characters themselves, as opposed to the underlying creative works in which they first appeared. Copyright law provides some level of protection for fictional characters that are sufficiently delineated. See, e.g., Goldstein, supra note 5, at $\$ 2.7 .2$, at 2:96; Nichols v. 
To be clear, under the proposal advanced in this Article, consideration of time in fair use analysis would not be dispositive. Nor would the proposal here have the effect of eliminating copyright protection for older works. Rather, time would be a factor to be weighed along with (and, no doubt, in some cases outweighed by) the other fair use factors. ${ }^{83}$ Older works would still enjoy substantial protection under copyright law, for example, against direct, commercial copying. However, they would have less protection against uses of the work that involve transformation or other traditionally fair uses. Thus Mickey Mouse would still have substantial protection against literal, commercial copying, even though he first appeared more than 60 years ago. ${ }^{84}$ However, Mickey would be exposed to a greater degree of other types of fair uses.

Consideration of time in fair use analysis would have significant benefits. Most notably, it would acknowledge the fact that many of the policies underlying the appropriate scope of copyright protection are affected quite directly by the passage of time. Current doctrine, by neglecting the passage of time, artificially treats the balance of competing policies as static over the term of copyright protection. While this may have been an appropriate approach when the copyright term was as short as 14 years, ${ }^{85}$ this approach is badly out of place today, now that copyright protection can extend more than 100 years. As shown in more detail below, ${ }^{86}$ authorial incentives, public access, the societal importance of copyrighted works, and an author's moral claim to the fruits of his or her creative labor are all affected by the passage time. Considering time would permit courts to adjust the scope of protection more dynamically to account for the impact of time on these various considerations. In this way, copyright doctrine would do a much better job of fulfilling the policies underlying it.

Moreover, consideration of time would be easy to implement, both doctrinally and practically. ${ }^{87}$ Currently, courts do not consider the length of time in their determinations of fair use. However, the Copyright Act expressly gives courts broad discretion to consider various relevant factors in determining whether a use is fair. Moreover, courts

Universal Pictures Corp., 45 F.2d 119 (2d Cir. 1930); D.C. Comics v. Reel Fantasy, 696 F.2d 24 (2d Cir. 1982).

${ }^{83} \mathrm{Id}$.

${ }^{84}$ See Steamboat Willy (1928).

${ }^{85}$ Although the maximum copyright term under the original 1790 act was 28 years, this consisted of an initial 14-year period, and an additional 14-year renewal period. If the copyright was not renewed, then the works passed into the public domain after 14 years. See Goldstein, supra note 5, at §4.7, at 4:138; Copyright Act of 1790, § 1, 1 Stat. 124 (1790).

${ }^{86}$ See infra Parts II.A through II.C.

${ }^{87}$ See infra Part III.A. 
have in the past considered additional factors in their fair use determinations. Thus, as a matter of pure doctrine, courts are fully authorized to consider time. And, as I will show below, policy justifications overwhelmingly support the consideration of time as a factor in fair use analysis. Thus, consideration of time would be a relatively simple and straightforward way of incorporating concerns about the length of the copyright term into existing copyright analysis, without disrupting the existing mode of copyright analysis.

Finally, consideration of time would permit courts to inject public-regarding values into an area of copyright law largely dominated by congressional response to lobbying interests. As mentioned above and developed in more detail below, ${ }^{88}$ the consistent pattern of expansion of the copyright term (and copyright scope more generally) is a rather direct result of a structural imbalance in lobbying power between copyright owners and consumers. Given that Congress appears unwilling or unable, as public choice theory predicts, to rein in such extensions in the duration of protection, the proposal in this paper provides courts with the ability to adjust the scope of copyright protection to account for this. Moreover, it would permit courts to do so safely within the existing doctrinal structure of copyright law - i.e. without reaching to create law, striking down congressional enactments, or in any way hindering the intent of Congress.

In advancing this proposal, let me be clear about my motives. I, like many other commentators, am troubled by the continuing expansion of copyright protection on a number of different fronts, of which term extension is only one. Specifically, I believe that many of these expansions find little or no support under any of the policy justifications underlying copyright law more generally. This is certainly true of term extension, which was opposed by nearly every copyright scholar in the country. ${ }^{89}$ At the same time, the prospect of congressional action in this arena is unlikely, given the structural imbalances in lobbying power. And constitutional challenges to congressional action may well not succeed. Thus, this proposal is quite consciously an attempt to look for ways, safely within existing doctrine, for courts to legitimately inject certain public-regarding values into the scope of copyright protection. ${ }^{90}$ For those who share this view, this proposal should be very attractive.

\footnotetext{
${ }^{88}$ See infra Part II.D.

${ }^{89}$ See, e.g., Karjala, Statement, supra note 8; Karjala, Statement, supra note 45.

${ }^{90}$ This proposal is thus likely what Jane Ginsburg was concerned about in writing that: "One unintended consequence of term extension, I fear, is to promote contentions that the only way to offset the excessive term of copyright is to cut back on the scope of copyright - to establish weaker derivative works protection or weaker protection across the board." See Ginsburg, et al., supra note 52, at 701. Others have suggested more generally that courts should interpret fair use expansively in light of extensions in the
} 
But even for those who do not share this view, the proposal should be very attractive, since the proposal stands very much on its own two feet. That is, as I will show below, the proposal finds exceptionally strong support under all of the underlying justifications for copyright law more broadly. It provides a more finely-calibrated balance between access and incentives, it encourages an appropriate amount of re-use and adaptation of existing works, and it provides more measured rewards to authors for their creative labor. These are all good reasons, within existing copyright law theory, to support the proposal. Thus, whatever one thinks about recent expansions in copyright protection, the proposal advanced in this Article will have significant benefits for copyright law more generally.

\section{THEORETICAL ARGUMENTS}

Before examining the doctrinal argument in support of my proposal, I want to establish that there's a reason to construct it in the first place - i.e. that time should matter in fair use analysis. As it turns out, an examination of a number of policy justifications underlying copyright law reveals that there is extremely strong support for considering time as a factor in fair use analysis. Indeed, the support is so strong that it is surprising that courts have yet to consider time in fair use analysis, at least explicitly, particularly given the vast current term of copyright protection.

\section{A. INCENTIVES AND ACCESS}

The primary policy justification for copyright protection in the U.S. is the incentive justification. ${ }^{91}$ The familiar argument goes like this: copyright protection is necessary to provide adequate incentives for authors to engage in creative activity. Without such protection, others could easily copy and distribute an author's works, quickly driving the price of the work down to the marginal cost of an additional copy. ${ }^{92}$ Authors would thus be unable to recoup the costs of their original

copyright term. See, e.g., Lydia Pallas Loren, Redefining the Market Failure Approach to Fair Use in an Era of Copyright Permission Systems, 5 J. INTELL. Prop. L. 1, 7 (1997) ("Under the current scheme of copyright, granting ever broader rights to copyright holders for ever longer periods of time, the guarantee of the right of fair use must be protected and even expanded."); see also Jessica Litman, Copyright \& Information Policy, 55 LAW \& CONTEMP. ProBs. 185, 207 \& n. 2 (1992).

${ }^{91}$ Although primary, this justification is certainly not exclusive. See infra Parts II.B and II.C.

${ }^{92}$ See, e.g., Netanel, supra note 59. 
creative labor. ${ }^{93}$ As a result, authors would not choose to engage in such labor in the first place, and creative works would not be produced in adequate numbers. ${ }^{94}$ Copyright law solves this problem by providing incentives to engage in creative labor, harnessing the economic selfinterest of authors for the benefit of society at large.

At first blush, the incentive argument would appear to justify further extension of the copyright term. ${ }^{95}$ After all, if some incentive is good, why isn't more incentive even better? The answer, familiar to traditional copyright law, is that protection comes at a cost. Copyright law provides incentives to authors, but only by enabling authors to restrict dissemination of the work. ${ }^{96}$ In economic terms, copyright law permits an author to raise the price of the work above the marginal cost of producing an additional copy. This provides an incentive to the author, but it also means that those who would have purchased the copy above marginal cost but below the price cannot get access to the work. ${ }^{97}$ Copyright law thus presents a tradeoff. ${ }^{98}$ Roughly speaking, depending on the strength of the protection, we can have more works but more restricted access, or fewer works with broader access. ${ }^{99}$

${ }^{93}$ But see Breyer, supra note 44 (arguing that this may not be the case in the market for books, in light of first-mover advantages and other factors); see also Barry W. Tyerman The Economic Rationale for Copyright Protection for Published Books: A Reply to Professor Breyer, 18 U.C.L.A. L. REV. 1100 (1981) (disputing Breyer's claims).

${ }^{94}$ The term "adequate" here is deliberately fuzzy, as much disagreement exists over what is adequate.

${ }^{95}$ As noted earlier, however, this justification cannot reasonably be applied to works that have already been created.

${ }^{96}$ See 1 T.B. Macaulay, Macaulay's SPeEches And Poems 285 (A.C. Armstrong \& Son 1874) ("It is good that authors should be remunerated; and the least exceptional way of remunerating them is by a monopoly. Yet monopoly is an evil. For the sake of the good we must submit to the evil; but the evil ought not to last a day longer than is necessary for the purpose of securing the good.").

97 This is the deadweight or static efficiency loss. See, e.g., Netanel, supra note 59; Richard J. Gilbert \& Michael L. Katz, When Good Value Chains Go Bad: The Economics of Indirect Liability for Copyright Infringement, 52 HASTINGS L.J. 961, 963-64 (2001).

98 See Glynn Lunney, Jr., Reexamining Copyright's Incentives-Access Paradigm, 49 VAND. L. REV. 483 (1996); Robert Cooter \& Thomas Ulen, LAW AND ECONOMICS 135 (1988) ("[T]he dilemma is that without a legal monopoly not enough information will be produced but with the legal monopoly too little of the information will be used.").

${ }_{99}$ Some commentators have argued that this loss can be avoided if the author can engage in price discrimination. See, e.g., Tom W. Bell, Fair Use vs. Fared Use: The Impact of Automated Rights Management on Copyright's Fair Use Doctrine, 76 N.C. L. REV. 557, 596-600 (1998); I. Trotter Hardy, Property (and Copyright) in Cyberspace, 1996 U. CHI. Legal F. 217; see also William Fisher III, Property and Contract on the Internet, 73 Chi.-Kent L. Rev. 1203, 1234-40 (1998); Harold Demsetz, The Private Production of Public Goods, 13 J. L. \& Econ. 293 (1970). Thus, for some (i.e. so-called "maximalists" or "neoclassicists"), an optimal term might be perpetual, assuming that the Constitution did not foreclose this option. See Netanel, supra note 59, at 367-68 ("Neoclassicism, therefore, has no reason to extinguish the owner's copyright after a term of years."). It 
Copyright law also presents another trade-off, this one not between authors and consumers, but between authors and other authors. It is a commonplace that new works draw from and build upon old ones. ${ }^{100}$ No work is purely and completely new. All works draw upon prior works, to at least some extent. Thus, by increasing protection for initial works, we may increase the incentives for producing such works, but we also increase the cost of producing works that draw upon these initial works. ${ }^{101}$ Thus, if protection is too great, we may in fact decrease the number of total works (i.e. the sum of both original and follow-on works). If our aim is to provide adequate incentives for both initial and follow-on works, the strength of copyright protection needs to be balanced. ${ }^{102}$

The length of the copyright term is one way (among many ways) in which this balance is struck. ${ }^{103}$ Too short a term, and incentives may not be sufficient, since authors may not have enough time to obtain sufficient compensation for their efforts. Too long a term, and the work may not be widely disseminated or built upon over time. ${ }^{104}$ The optimal

isn't clear to me, however, that the conditions that would permit perfect (or even close to perfect) price discrimination exist in real copyright markets. See, e.g., Michael Meurer, Copyright Law and Price Discrimination, 23 Cardozo L. Rev. 55 (2001); Carl Shapiro \& Hal Varian, Information Rules: A Strategic Guide to the Network EConomy 53 (1999); Joseph P. Liu, Owning Digital Copies: Copyright Law and the Incidents of Copy Ownership, 42 Wm. \& Mary L. Rev. 1245, 1321-22 (2001). Moreover even if they did, other more fundamental objections (including the one in the following paragraph) exist to this price discrimination model. See, e.g., Wendy Gordon, Intellectual Property as Price Discrimination: Implications for Contract, 73 CHI.-Kent L. REV. 1367, 1369 (1998); Boyle, supra note 47; Julie Cohen, Copyright and the Perfect Curve, 53 VAND. L. REV. 1799 (2000); Yochai Benkler, An Unhurried View of Private Ordering in Information Transactions, 53 VAND. L. REV. 2063 (2000); Netanel, supra note 59, at 368; Julie Cohen, Lochner in Cyberspace: The New Economic Orthodoxy of "Rights Management", 97 Mich. L. REV. 462 (1998); Loren, supra note 26..

${ }^{100}$ See Litman, supra note 24, at 966-67 ("But the very act of authorship in any medium is more akin to translation and recombination than it is to creating Aphrodite from the foam of the sea."); Paul Goldstein, Derivative Rights and Derivative Works in Copyright, 30 J. COPR. SOC'Y U.S.A. 209, 218 (1983).

${ }^{101}$ See William Landes \& Richard Posner, An Economic Analysis of Copyright Law, 18 J. LEG. STUD. 325, 333 (1989); Gilbert \& Katz, supra note 97, at 964-65.

102 See Landes \& Posner, supra note 101; Mark Lemley, The Economics of Improvement in Intellectual Property Law, 75 TEX. L. REV. 989 (1997); Netanel, supra note 59, at 295 ("An overly expanded copyright also constitutes a material disincentive to the production and dissemination of creative, transformative uses of preexisting expression.")

${ }^{103}$ See Twentieth Century Music Corp. v. Aiken, 422 U.S. 151, 156 (1975) ("The limited scope of the copyright holder's statutory monopoly, like the limited copyright duration required by the Constitution, reflects a balance of competing claims upon the public interest: Creative work is to be encouraged and rewarded, but private motivation must ultimately serve the cause of promoting broad public availability of literature, music, and the other arts.").

${ }^{104}$ See Walterscheid, supra note 74, at 359 (discussing this balance). 
or ideal copyright term is probably impossible to determine in any meaningful way. ${ }^{105}$ Indeed, the sparse academic literature on this point has provided no firm guidance. ${ }^{106}$ Different types of works may require different lengths of protection (for example, protecting software for 10 years would probably be sufficient, at least under today's market conditions, given how quickly software becomes obsolete) ${ }^{107}$. Even within a given type of work, much might depend on how the market is structured at that particular time, what other incentives exist, etc. Thus, a high degree of uncertainty will inevitably attend discussions about the proper term. The precise number chosen will always be, to some extent, arbitrary. ${ }^{108}$ Thus Congress should properly be given some degree of discretion in setting the term. ${ }^{109}$

Even conceding a good degree of Congressional discretion, however, there are good reasons to believe that the current period is too long, i.e. that it substantially hinders access without a corresponding benefit in incentives. ${ }^{110}$ Under an incentive justification, the reason for

\footnotetext{
105 See H. Rep. No. 94-1476 at 133, reprinted in 1976 U.S.C.C.A.N. 5659, 5749 ("The debate over how long a copyright should last is as old as the oldest copyright statute and will doubtless continue as long as there is a copyright law."); Netanel, supra note 59, at 369 ("[I]t is difficult, if not impossible, to determine with any degree of precision the term of copyright that would lead to optimum support for creative autonomy, while still allowing for sufficient user access.")

${ }^{106}$ Indeed, it is somewhat surprising that so little has been written on copyright term. But see Walterscheid, supra note 74, at 359-60; Edward C. Walterscheid, The Remarkable-And Irrational--Disparity Between The Patent Term And The Copyright Term, 83 J. PAT. \& Trademark Off. SOC'y 233 (2001); Robert L. Bard \& Lewis Kurlantzick, Copyright Duration: Duration, Term Extension, The European Union, and the Making of Copyright Policy (1999); Saul Cohen, Duration, 24 UCLA L. ReV. 1180 (1977); Richard Epstein, Intellectual Property: Old Boundaries and New Frontiers, 76 IND. L.J. 803, 825 (2001) (discussing duration). See also Lessig, supra note 59 (proposing a 10-year term); James Boyle, Shamans, SofTwARE AND SPLEENS: LAW AND THE CONSTRUCtion of THE INFORMATION SOCIETY 172 (1996) (suggesting a 20-year term). Comparatively more attention appears to have been paid to the term of patent protection. See, e.g., Richard Gilbert \& Carl Shapiro, Optimal Patent Length and Breadth, 21 Rand J. Econ. 106 (1990); Paul Klemperer, How Broad Should the Scope of Patent Protection Be?, 21 Rand J. Econ. 113 (1990).

${ }^{107}$ See Ralph Brown \& Robert Denicola, CASES On Copyright, Unfair Competition, and Related Topics Bearing on the Protection of Literary, Musical, and ARTISTIC WORKS 487 (7th ed. 1998) (suggesting possibility of varying terms depending on nature of the work).

${ }^{108}$ The discussion here focuses on how long the copyright term should be as a matter of theory. For a historical explanation for the copyright term, see Walterscheid, supra note 74 , at 381-86.

${ }^{109}$ See Eldred, 239 F.3d at 380; Sony Corp. v. Universal City Studios, 464 U.S. 417, 429 (1984); Stewart v. Abend, 495 U.S. 207, 230 (1990). Note, however, that such discretion also provides a strong incentive for interested parties to petition for extensions of the time period.

${ }^{110}$ See Ginsburg, et. al., supra note 52677 (2000) (comments by Wendy Gordon) (suggesting that an instrumentalist would oppose extension because it "provides twenty
} 
the copyright extension is that it will increase the incentives for the creation of new works. However, as a matter of simple economics, additional increases in the term of copyright result in ever-decreasing amounts of additional incentive. For the vast majority of works, there will probably be little demand more than 50 years after the death of the author. ${ }^{111}$ For those few works that still retain some market value, however, the present value of any future income streams will be miniscule. ${ }^{112}$ This is because of the simple economic phenomenon of the time value of money. ${ }^{113}$

To see this, take the following example. ${ }^{114}$ Assume, for simplicity's sake, that an author creates a work in 2000 and dies immediately thereafter. The term of protection under the 1976 Act would have been until the year 2050. ${ }^{115}$ However, under the term extension, the term will now expire in 2070. What was the incentive value of that additional 20 years? Let's assume a discount rate of $10 \%$. Let's further assume for now that the author is one of the very fortunate few, whose work is still generating some revenue for his estate from 2050 through 2070 . If the work generated one dollar each year for the period from 2050 through 2070, the net present value of that cash flow

more years of making works expensive and difficult to access, without giving a compensating gain in incentives); Lloyd Weinreb, Copyright for Functional Expression, 111 HARV. L. REV. 1149, 1244 (1998) (“It is scarcely credible that authors' or publishers' decisions, say, in 1998 will be affected by rights that their successors will have in 2073 and thereafter."); Ginsburg, supra note 29, at 171 ("The [retroactive portions of the] law thus cannot enhance the quantum of creativity from the past, but it can compromise the creativity of the future, by delaying for twenty years the time at which subsequent authors may freely build on these works.")

111 See Goldstein, supra note 5 ("According to the 1961 Report of the Register of Copyrights, fewer than fifteen percent of all copyrights were renewed under the 1909 Act”).

112 See Affidavit of Hal Varian, submitted in Eldred v. Reno, 74 F. Supp. 2d 1 (D.D.C. 1999), available at, http://cyber.law.harvard.edu/eldredvreno/varian.pdf (visited Feb. 1, 2002) ("In my opinion, extending current copyright terms by 20 years for new works has a tiny effect on the present value of cash flows from cretive works and will therefore have an insignificant effect on the incentives to produce such works").

${ }^{113}$ See Merges, supra note 58, at 2236 ("From an incentive point of view, the Act is virtually worthless; viewed from a present-value perspective, the additional incentive to create a copyrightable work is negligible for an extension of copyright from life-plus-fifty years to life-plus-seventy years.”); Robert C. Denicola, Freedom to Copy, 108 YALE L.J. 1161, 1679 (1999) ("At some point, attempts to defend increased duration on incentive grounds become implausible because of the decreasing time value of money."); Breyer, supra note 44, at 324 ("More probably authors, like others, discount the value of future income, and, when discounted, the present value of a future copyright advantage is small.”).

${ }^{114}$ This example is adapted from the Varian, supra note 112.

115 Note that this understates the copyright term, since if the author had been 40 at the time of authorship and lived to the average life expectancy of 75 , this would have added 35 more years to the term, pushing the term of protection out to 85, expiring in 2085 . 
would be about 8 cents. ${ }^{116}$ Assume that the work is successful, even that far out into the future, generating say $\$ 100,000$ per year. The present value of that cash flow would be approximately $\$ 8,000$. Moreover, we have assumed that the return is absolutely certain. If we instead discount that amount further by the uncertainty associated with receiving revenue 50 years later, the amount would be even less. If, for example, only $1 \%$ of published novels have any kind of staying power 50 years later, the expected value would be $\$ 80 .^{117}$ Thus, in order to accept the incentive justification, one would need to believe that the prospect of an additional $\$ 80$ to the author in 2000 would be sufficient to result in an appreciable increase in creative effort. ${ }^{118}$

Yet one needn't accept this argument, or even believe that the current period is too long, to accept the argument that time should at least have some impact on the level of protection. That is because, if we accept the incentive argument for copyright protection, the value of the incentive to the author decreases as the term of the copyright gets longer. This is again the result of the time value of money. Revenue from the first ten years of protection is more valuable than revenue from the next (assuming the amounts of revenue are the same), because the revenue from the next ten years is subject to a greater period of discounting. ${ }^{119}$ And so on. Thus, the present value, and therefore incentive impact, of revenue in the last 20 years of a copyright's term is far less than the first. In the example above, assuming the same revenue received in the first 20 years, the net present value of that cash flow, even prior to discounting to account for the probability of success, would be more than $\$ 700,000$ compared to $\$ 8,000$ from the last 20 years. ${ }^{120}$ Accordingly, under the

\footnotetext{
${ }^{116}$ The present value of a future payment of $\$ 1$ is $1 /(1+r)^{\wedge} n$, where $r$ is the discount rate and $\mathrm{n}$ is the number of years in the future when the payment is made. See Varian, supra note 112. The 8-cent figure is simply the sum of the present values for $\$ 1$ payments from years 50 through 70 .

${ }^{117}$ This figure is likely generous. Rates of copyright renewal under the pre-1976 regime are an indicator of the economic value of copyrighted works over time. These renewal rates suggest that the vast majority of works did not have sufficient value to warrant even the minimal cost of renewal, even 28 years after publication. See Goldstein, supra note 5 ("According to the 1961 Report of the Register of Copyrights, fewer than fifteen percent of all copyrights were renewed under the 1909 Act"); Barbara A. Ringer, Renewal of Copyright, in 1 Copyright Society of the U.S., Studies on Copyright 503, 617 (Fisher Mem. ed. 1963).

118 This analysis is, admittedly, simplified. To get a truly accurate picture of the incentives involved, one would need to have more concrete data on the range of different possible income streams for various types of works, and the likelihood of each income stream in fact occurring, etc. However, the analysis does at least give a rough impression of how time impacts the value of income streams that far in the future.

${ }^{119}$ See Varian, supra note 112.

${ }^{120}$ Thus the incentive impact of the last 20 years is just little over $1 \%$ of the impact of the last 20 years. And again, even this understates the differential, since it does not adjust for
} 
incentive view, the further out we go in the term, the less we should be concerned about the incentive effects of finding no or less protection. ${ }^{121}$

Conversely, there may be quite strong reasons to be concerned about ensuring widespread access over time. In particular, the more time that elapses, the more difficult it will be for a potential purchaser or licensor to determine who owns the copyright. ${ }^{122}$ The problems associated with finding the holders of copyrights have been welldocumented. ${ }^{123}$ In some cases, a work may no longer be published. ${ }^{124}$ In other cases, difficulties may result because the original author is deceased, and the heirs or devisees need to be identified and contacted. Alternatively, the copyright may have been transferred to other parties, perhaps several times, and the most recent holders must be identified and contacted. There may also be a good deal of uncertainty over who exactly owns the rights, due to the rather complex provisions of the Copyright Act involving renewals, ${ }^{125}$ termination of transfer, and inheritance. Finally, complexities about formalities, renewal and copyright term extension may bring into doubt whether the work is even still copyrighted. All of these considerations increase as the time period extends and records and memories grow thin, ${ }^{126}$ thus making access to

the very likely possibility that revenue streams would significantly be reduced (perhaps to nothing) as the work becomes older.

${ }^{121}$ Note that this holds even under theories of copyright law that argue that the incentive impact results, not necessarily from the return from any given work, but from the potential of at some point creating a work that generates an exceptional amount of revenue. Cite "prize" literature. Even under this view, the future revenues from a "hit" must be discounted over the lengthy copyright term. Similarly, the analysis applies as well to arguments sometimes made that extension of the copyright term is intended to benefit an author's descendants, since the amount of this benefit is subject to discounting as well. See Ginsburg, supra note 29, at 172 ("The 1976 Act term already allowed authors to provide for children and grandchildren; will the addition of greatgrandchildren to the prospective beneficiaries of the author's work likely inspire the creation of another song or sequel?").

${ }^{122}$ See Landes \& Posner, supra note 101; Robert Cooter \& Thomas Ulen, Law and Economics 125 (2d ed. 1997) (discussing tracing costs).

${ }^{123}$ See, e.g., Frances Nevins, Little Copyright Dispute on the Prairie: Unbumping the Will of Laura Ingalls Wilder, 44 ST. LOUIS U. L. REV. 919 (2000) (documenting dispute over copyright ownership of Little House on the Prairie series).

${ }^{124}$ See Breyer, supra note 58 ("[A]s time passes persons wishing to reproduce old articles, books, designs, or other writings find it progressively harder to find the copyright owner to secure permission - particularly when copying is necessary because, for example, a book is out of print.").

${ }^{125}$ See 17 U.S.C. $\$ 304$.

126 A number of commentators, in discussing term extension, have argued that to accurately balance the costs and benefits of term extension, we need to discount both the costs and the benefits. See Breyer, supra note 44, at n. 181; see also Hatch, supra note 7, at 736. That is, just as we discount the future revenue streams from additional protection, we should also discount the loss to consumers from extension. See Hatch, supra note 7, at 736. Even if this is true, this does not undercut the proposal in this Article, since what 
the work more problematic as time passes. ${ }^{127}$ Indeed, these costs have been viewed by some as the primary policy reason for the limited term. ${ }^{128}$

In addition, as time passes, the interest in having works that build upon the original increases. As mentioned above, one of the tradeoffs in copyright law involves balancing incentives between initial works and follow-on works. ${ }^{129}$ The elements of this tradeoff vary across time. In the initial years of a copyright's term, we are more concerned with compensating the initial author for his or her creative labor, since these years have the greatest level of incentive effect. However, over time, as shown above, that incentive wanes. Conversely, as developed in more detail in the following section, the longer a work is out, the more it becomes a likely candidate for others to build upon. That is, it becomes part of the stock of works that future authors have encountered and read, and upon which they might want to build. Indeed, for some particularly famous works, there may effectively be no reasonable substitutes. ${ }^{130}$ Even if it might be possible to license such a derivative work from the copyright holder, any license fee (not to mention the tracing costs already mentioned above) serves to increase the cost (and reduce the incentives) for such follow-on works. Accordingly, to the extent that we are

is relevant is not an absolute comparison of costs and benefits as we progress further out in the copyright term. Instead, what is relevant is the relative importance of costs and benefits over time. That is, costs can be expected to increase as we progress further out in the copyright term, whereas revenues can generally be expected to stay constant or, more likely, decrease as the work fades in importance. (This latter assumption, while probably true in most cases, may not be true in all, and I discuss these cases in Part IV.B, infra). Thus, even if we discount both costs and benefits, the relative weight of these two factors can be expected to change over the copyright term, thus lending support to the proposal that time should make a difference.

${ }^{127}$ See 2 Goldstein, supra note 5, at $\S 10.1 .1$. Although this is a general rule, there may, of course, be exceptions. For example, there is little doubt about who owns the rights to Mickey Mouse. Thus, in some cases, time may not accurately reflect this interest. However, I will address this in more detail below in Part IV.B, as part of my general response to the objection that time is merely a proxy for other factors that should be considered expressly.

${ }^{128}$ See Landes \& Posner, supra note 101; Cohen, supra note 106, at 1185 (1977); see also White-Smith Music Publishing Co. v. Apollo Co., 209 U.S. 1, 19 (1907) (Holmes, J.).

${ }^{129}$ See Lemley, supra note 102.

${ }^{130}$ See Wendy Gordon, Property Right in Self-Expression: Equality and Individualism in the Natural Law of Intellectual Property, 102 YALE L.J. 1533 (1993); Ginsburg, et al., supra note 52 (statement of Wendy Gordon). Cf. Breyer, supra note 44, at 324 (suggesting that owners of copyrights in works that achieve "classic" status may be subject to less price competition since there will be fewer substitutes). 
interested in balancing incentives for both initial and follow-on works, fair use should vary over time under this incentive rationale as well. ${ }^{131}$

Thus even if we cannot say with any certainty what the optimal length of the copyright term should be, we can say with very good confidence that time should at the very least be relevant under the incentive justification, and that fair use analysis should properly be sensitive to the impact of time on incentives and access. The longer a work has been out, the weaker the incentive claim and the greater the access claim. Thus, one would expect the scope of fair use to increase over time, under the incentive view.

\section{B. ENCOURAGING RE-USE AND CRITIQUE}

Sometimes, one hears a variation of the incentive argument that goes like this. Copyrights (and other intellectual property rights) are needed, not only to provide incentives for the initial creation of creative works, but also for their orderly exploitation. That is, we give exclusive rights to copyright owners, not only so that they have an incentive to write a given book, but so they can also have control over sequels, movies based on the book, etc., etc. Although this line of argument has been most powerful in the field of patents, ${ }^{132}$ it has a related influence in copyright and in particular in the area of derivative works. The basic idea is that we want only one party to have control over Mickey Mouse. ${ }^{133}$ Imagine if anyone in the world could make their own Mickey Mouse movie. We would soon have different versions of Mickey (e.g. evil Mickey, Mickey in space, an asian Mickey, etc., etc.), and the value created by the original author would be dissipated. Thus, copyright law needs to extend protection to works to provide for orderly development. ${ }^{134}$

As an initial matter, there are serious theoretical problems with this justification for copyright law. Unlike patent law, copyright law is, in Paul Goldstein's terms, centrifugal rather than centripetal. ${ }^{135}$ Patent law deals with inventions and processes, and the overarching ideal is

${ }^{131}$ See Lemley, supra note 102, at 999 ("The limited duration of patents and copyrights promotes improvements in writings and inventions, by allowing subsequent authors and inventors to build upon what came before them.").

132 See, e.g., Edmund Kitch, The Nature and Function of the Patent System, 20 J.L. \& ECON. 265 (1977).

133 See Lessig, supra note 9; Justin Hughes, "Recoding” Intellectual Property and Overlooked Audience Interests, 77 TEX. L. REv. 923 (1999).

${ }^{134}$ See Hughes, supra note 133; Landes \& Posner, supra note 101.

${ }^{135}$ See Paul Goldstein, Infringement of Copyright in Computer Programs, 47 U. Pitt. L. Rev. 1119, 1123 (1986) ("The aim of copyright is to direct investment toward abundant rather than efficient expression."). [Note Goldstein does not necessarily draw the same conclusion, as a result]. 
efficiency. That is, we want technology and innovation to converge on the most efficient solution or set of solutions. Under such conditions, orderly development of technology may make sense. By contrast, copyright seeks a diversity of expression. It is designed in many ways to permit variations, new expressions built upon existing ideas. ${ }^{136}$ Thus, we are not terribly disturbed by the idea that anyone at all can make a movie re-telling, in any form, the story of Romeo and Juliet, ${ }^{137}$ - indeed, this is seen as a good thing, not a bad thing. The prospect theory thus has more limited application in the copyright arena.

However, even within the "prospect" justification, there is ample support for the idea that the scope of this right should vary with time. It may well be that an author should be given some period of time during which to develop or control variations or derivatives based upon the original work. This could partly be based on a straight incentive rationale and partly based on a prospect rationale. Over time, however, that interest lessens, since the author has had ample opportunity to engage in such development. Thus, it may be fair to give an author at least 10 , perhaps 20 or even a lifetime of years to write a sequel or several sequels. ${ }^{138}$ But if she hasn't written a sequel after 70 years, perhaps her interest in orderly development is more attenuated and others should be permitted to build more aggressively on the work ${ }^{139}$. Or if, alternatively, she has written 20 sequels in the intervening years, she may have had ample opportunity again to have exploited such variations, and the work should be subject to more perspectives. Either way, such an interest should, like the incentive interest, grow weaker as time passes. Thus, under either of the incentive views, strong arguments support the increase in the scope of fair use over time.

At the same time, society's interest in seeing different perspectives and re-interpretations of the original work increases over time. Indeed, a number of commentators have argued that copyright must do more to actively support an interest in the re-interpretation of copyrighted works. ${ }^{140}$ In recent years, a number of scholars have

${ }^{136}$ See id.; Robert Merges, Are You Making Fun of Me? Notes on Market Failure and the Parody Defense in Copyright, 21 AIPLA Q.J. 305 (1993); Gordon, supra note 130.

${ }^{137}$ Compare William Shakespeare, The TrAgEdy OF RomeO AND JuliET, with West Side Story (1961), Romeo + Juliet (1996).

${ }^{138}$ Cite literature on copyright suppression, unpublished works.

${ }^{139}$ Certainly this interest would not exist if she were already dead.

${ }^{140}$ See, e.g., Rosemary Coombe, Objects of Property and Subjects of Politics: Intellectual Property Laws and Democratic Dialogue, 69 TeX. L. REV. 1853 (1991); Rosemary Coombe, The Cultural Life of Intellectual Properties: Authorship, APPROPRIATION, AND THE LAW (1998); Rochelle Cooper Dreyfuss, Expressive Genericity: Trademarks as Language in the Pepsi Generation, 65 Notre DAME L. ReV. 397 (1990); David Lange, At Play in the Fields of the Word: Copyright and the Construction of Authorship in teh Post-Literate Millennium, 55 LAW \& ConTEMP. ProbS., Spring 1992, 
critiqued the recent expansion of intellectual property law, focusing in particular on the extent to which the expansion hinders the ability of others to re-cast, transform, and derive new meanings from existing copyrighted works. These arguments have been particularly forceful in the areas of trademark law and the right of publicity. The basic claim is that third parties, in order to meaningfully make sense of certain intellectual goods, must have some degree of freedom to play with such goods, to re-cast them, to imbue them with meanings independent of the ones that the original author intended. These activities are an essential part of what it means to consume an intellectual good. ${ }^{141}$ Although these scholars recognize the need to provide incentives for the creation of such works, they are concerned that the scope of protection not be so expansive as to limit essential critique and transformation. ${ }^{142}$

These interests provide further support for consideration of time in fair use analysis. Again, one need not buy the argument in its entirety or even agree with any particular implementation of the argument; one need only recognize that time has an impact on the relative importance of this value. As discussed above, over time, the original author's interest in controlling orderly exploitation of the work wanes. At the same time, as time passes, the copyrighted work is more likely to be part of the common stock of works and ideas that others have encountered and wish to build upon. The longer a work has been published, the more desirable it becomes as material for discussion or re-casting. The longer a work has been out, the more likely it is that other authors will have encountered it and wish to build upon it or incorporate it into their own subsequent works. ${ }^{143}$

Copyright law already recognizes this to some extent (in theory, if not in practice) ${ }^{144}$, through the limited copyright term. As their

at 139; Michael Madow, Private Ownership of Public Image: Popular Culture and Publicity Rights, 81 Cal. L. ReV. 127 (1993); Jane Gaines, Contested Culture: The Image, The Voice, And the Law (1991). See Liu, supra note 99 Owning Digital Copies: Copyright Law and the Incidents of Copy Ownership, 42 Wm. \& Mary L. Rev. 1245, 1327-29 (2001). But see, Hughes, supra note 133.

${ }^{141}$ See Lange, supra note 140.

${ }^{142}$ See also Netanel, supra note 59, at 369 (deriving limit from copyright's role in creating conditions for a democratic civil society).

${ }^{143}$ See Note, supra note 10, at 1209 (proposing that courts deciding cases involving an author's re-telling of another's literary work expressly consider whether the original work "occupies a place of such culturally iconic status that not to permit a re-writing of it would suppress important and necessary discussion of that work.")

${ }^{144}$ The extension of the copyright term is but one of the ways in which passage of copyrighted works into the public domain has been hindered. Prior to 1976, U.S. copyright law required compliance with a number of formalities, such as notice, and if such formalities were not observed, a work would pass into the public domain. Thus, many works in fact passed into the public domain as a result. However, in 1976, 
copyright terms expire, works pass from protected status into the public domain, where they can be freely built upon, transformed, re-cast, and re-imagined by others. Indeed, according to many commentators, the public domain's primary purpose is not so much to reduce the costs consumers pay for copyrighted works, or to serve as a repository for works that are not worth protecting. ${ }^{145}$ Instead, its purpose is to serve as a robust area of material from which subsequent authors are free to draw for their own works, without concerns about infringement or securing licenses from copyright owners. ${ }^{146}$ Thus anyone can re-tell the classic story of two star-crossed lovers in any form, without first seeking a license to do so. Similarly, companies like Disney can mine the public domain for stories, which they can then re-tell and reimagine into their own copyrighted works.

A number of scholars have, in fact, focused a good deal of recent attention on the public domain as a concept, with an eye toward articulating a cogent theory of the public domain to serve as a counterweight to the recent expansionist tendency of intellectual property law. ${ }^{147}$ These scholars have been concerned about these expansions and

Congress eliminated such formalities as a prerequisite for copyright protection. As a result, since that date, this avenue for passage into the public domain has been closed.

${ }^{145}$ See Litman, supra note 24, at 967-68.

${ }^{146}$ See id., at 968 ("The public domain should be understood not as the realm of material that is undeserving of protection, but as a device that permits the rest of the system to work by leaving the raw material of authorship available for authors to use.").

${ }^{147}$ See James Boyle, The Second Enclosure Movement and the Construction of the Public Domain, 52 DuKE L.J. ___ (forthcoming 2002); Pamela Samuelson, Digital Information, Digital Networks, and the Public Domain, 52 DukE L.J. __ (forthcoming 2002); Elinor Ostrom \& Charlotte Hess, Artifacts, Facilities, and Content: Information as a CommonPool Resource, 52 Duke L.J. ___ (forthcoming 2002); see generally Conference on the Public Domain, Duke University Law School (Nov. 9-11, 2001); see also Boyle, supra note 106, at 363 (1996); James Boyle, A Theory of Law and Information: Copyright, Spleens, Blackmail, and Insider Trading, 80 CALIF. L. REV. 1415 (1992); Yochai Benkler, Free as the Air to Common Use: First Amendment Constraints on Enclosure of the Public Domain, 74 N.Y.U. L. REV. 354 (1999); Patterson, Understanding, supra note 74 , at 368 ("A major purpose of copyright ... is to protect the public domain, an idea that may be counter-intuitive, but is also irrefutable."); Netanel, supra note 59, at 368; Peter Jaszi, Goodbye to All That - A reluctant (and Perhaps Premature) Adieu to a Constitutionally-Grounded Discourse of Public Interest in Copyright Law, 29 VAND. J. Transnat'L L. 595 (1996); Keith Aoki, Authors, Inventors and Trademark Owners: Private Intellectual Property and the Public Domain, 18 Colum.-VLA J.L. \& ARTS 1, 191 (1994).; Paul Heald, Reviving the Rhetoric of the Public Interest: Choir Directors, Copy Machines, and New Arrangements of Public Domain Music, 46 Duke L.J. 241 (1996); Edward Samuels, The Public Domain in Copyright Law, 41 J. Copyright Soc'Y U.S.A. 137 (1993). This rich body of recent literature draws from earlier works analyzing the value of the public domain. See L. Ray Patterson \& Stanley Lindberg, THE NATURE OF COPYRight: A LAW OF USERS' Rights (1991); Litman, supra note 24; Lange, supra note 24, at 147; Gordon, supra note 130, at 1562. See also Benjamin Kaplan, AN 
the apparent lack of any structural mechanisms to counterbalance such expansions. Accordingly, they have begun to work towards articulating in a concrete manner the benefits that derive from a robust public domain and, conversely, the harm associated with granting ever-stronger private rights over information. According to these scholars, the eventual passage of works into the public domain is an essential feature of our existing copyright structure. ${ }^{148}$

What has been less widely acknowledged has been the way in which works begin this passage even during the term of protection. That is, certain copyrighted works can take on more and more public character over time as they become more entrenched in popular consciousness and culture. Consider, for example, the iconic status of Mickey Mouse. In the early days, the cultural meaning attached to Mickey was probably not much more than the meaning attached to other cartoon characters of the time. Over time, however, Mickey has come to signify much more in our society and become a target for recasting and a focal point for alternate meanings. ${ }^{149}$ In many ways, the public's claim on Mickey has increased over time, even during its period of copyright protection. ${ }^{150}$ Indeed, many authors have thoughtfully analyzed the extent to which certain images, symbols, and characters may be necessary for us to engage in dialogue about popular culture and our surroundings. ${ }^{151}$ As time passes, works begin the passage from pure products of creative expression to objects that are part of our collective cultural history. ${ }^{152}$

Or, to take a narrower doctrinal example, consider how such things as stock characters or scenes a faire come to be stock characters and scenes a faire. A work, character, or scene might start out its life as pure expression but, over the passage of time, start to resemble more closely a pure idea, a stock character, or a stock scene as the public is exposed to it and as others build and elaborate upon it. ${ }^{153}$ The first

UnhurRied View of Copyright (1966); Ralph Brown Jr., Unification: A Cheerful Requiem for Common Law Copyright, 24 U.C.L.A. L. REV. 1070 (1977).

148 See Netanel, supra note 59, at 368 (proposing a democratic approach to copyright scope that "would hold that works should at some point become a part of our common cultural heritage because they have considerable social value, not simply because of market failure."),

${ }^{149}$ See, e.g., Walt Disney Prods. v. Air Pirates, 581 F.2d 751 (9th Cir. 1978), cert. denied, 439 U.S. 1132 (1979). Cite other examples.

${ }^{150} \mathrm{An}$ analog to this is can be found in the trademark doctrine of genericism. See Dreyfus, supra note 140; Coombe, Objects, supra note 140.

${ }^{151}$ See Litman, supra note 24, at 1013-1017 (describing the way in which certain works "seep" into common usage). But see 2 Goldstein, supra note 5, at _ (discussing satire).

152 Trademark law's genericity doctrine shares this characteristic. See, e.g., Dreyfus, supra note 140.

${ }^{153}$ See Litman, supra note 24, at 1016-17 ("Some aspects of works of authorship are easily absorbed, and once we have absorbed them, we are likely to make them our own 
person to write a scene involving a villain tying a heroine to the train tracks $^{154}$ or a story involving a hard-boiled private detective might have created something that involved almost pure expression, and thereby acquired broad preemptive rights. However, over time, such scenes and characters become stock scenes and characters, moving from expression towards idea, ${ }^{155}$ from the realm of pure private protection toward the public domain. ${ }^{156}$

This view of the public claim on cultural works has been critiqued my a number of commentators. For example, Jane Ginsburg has sharply critiqued the attempt by some commentators to shift the focus of copyright away from authors and towards the audience. ${ }^{157}$ In particular, she has objected to the strains of this literature that draw heavily from post-modern and critical cultural theories, arguing that they go too far in eliminating the privileged role that authors have in copyright law. Similarly, others have analyzed audience interests and concluded, not that such interests require greater transformative potential, but that audiences also have an interest in the stability of the meaning of cultural artifacts. ${ }^{158}$ Thus, the argument that the public has some claim on a work is not uncontroversial.

One need not, however, go so far as to eliminate or greatly reduce consideration of author interests to recognize that an author's interest may be affected by the passage of time. Similarly, recognition that time may increase the public's claim on a work again does not result in complete failure to examine the author's initial interests. Instead, one only needs to recognize that both of these interests exist, and that the balance between them is affected by the passage of time. In the initial years, authorial interests are their greatest. But over time, these interests wane, and the public claim on the work increases. We may differ over precisely when and where the balance shifts. And to the extent any of the critiques of these views reject public claims on private works of

and lose sight of their origins. Ideas, information, short phrases, simple plots, themes, stock scenes, and utilitarian solutions to concrete problems all share this characteristic.").

${ }^{154}$ Thanks to my colleague Alfred Yen for suggesting this example.

155 This Article has focused on fair use as the doctrinal avenue for considering time as a factor in setting the scope of copyright protection. It is possible that time could have an impact on other copyright doctrines as well, such as the idea/expression dichotomy and the scenes a faire doctrine. For the purposes of this Article, however, I have focused on fair use because, as demonstrated in the following section, it provides the easiest and clearest doctrinal avenue for consideration of time-related interests.

${ }^{156}$ Indeed, at the extremes, protection for certain works might have first amendment implications, where there are no other adequate avenues for expression. Cite 1 st am. literature.

${ }^{157}$ See Jane Ginsburg, Authors and Users in Copyright, 45 J. COPYRIGHT SOC'Y U.S.A. 1 (1997)

${ }^{158}$ See Hughes, supra note 133. 
intellectual property works entirely, we certainly differ. But the proposal in this paper requires, at bottom, simply recognition of this balance.

Given that this process, this movement from purely private to public, is a gradual one, it is a bit odd that copyright protection does not, at least expressly, recognize this in setting the scope of protection, but rather provides full protection up to the end of the copyright term, and then none at all. Consideration of time in fair use analysis would have the desirable result of permitting more extensive transformation, critique, and re-use of copyrighted works over time. Although this interest has admittedly not played as central a role in setting the copyright balance, we might expect this interest to be more relevant as the copyright term extends to keep many more works from falling into the public domain. In any event, consideration of time would have the beneficial effect of permitting the scope of such transformation, critique, and re-use to vary over time.

\section{REWARDing AUthors}

The incentive argument discussed above is by far the most important and influential justification for copyright under U.S. law. Thus, the arguments above should by themselves be sufficient to give most courts reason to adopt time as a factor in fair use. However, in recent years, other non-economic theories of copyright law have begun to make inroads. Although they do not approach the incentive argument in importance or influence, I will address them here at least briefly and show how they, too, do not stand in the way of, and in some ways actively support, the proposal.

The strongest of these alternative theories has been the author reward argument. Based in part on the writings of John Locke, this justification holds that copyright law acts as a reward for the creative labor of authors. ${ }^{159}$ Unlike the incentive argument, the author reward argument is not based on the idea that authors should be rewarded in order provide greater benefits for society more generally. Rather, the argument is that the authors have a moral claim to their creative works, based on natural law. This argument often finds expression not only in specific judicial opinions and particular features of copyright law, but

${ }^{159}$ See, e.g., John Locke, Two Treatises on Government (3d ed. 1698); Justin Hughes, The Philosophy of Intellectual Property, 77 GEO. L.J. 287 (1988); Gordon, supra note 130; Alfred Yen, Restoring the Natural Law: Copyright as Labor and Possession, 51 Оніо Sт. L.J. 517 (1990); Lawrence C. Becker, Deserving to Own Intellectual property, 68 Chi.-Kent L. Rev. 609 (1993); R. Anthony Reese, Note, Reflections On The Intellectual Commons: Two Perspectives On Copyright Duration And Reversion, 47 STAN. L. REV. 707 (1995) (analyzing features of copyright term under competing views of Lockean labor theory). 
also in common intuitions about fair treatment of authors and creators. That this justification has force can clearly be seen from the fact that copyright law fully protects works that would have been created even without any financial incentive (for example, research papers, letters, diary entries, etc.). ${ }^{160}$ Certainly, copyright legislation is often influenced by these moral claims from authors. ${ }^{161}$

The author reward justification has come under attack on a number of grounds. ${ }^{162}$ In particular, to the extent that this argument is based on Lockean notions of labor-desert, some have questioned whether Locke's famous sufficiency proviso is satisfied, i.e. whether there is "enough and as good" for others. ${ }^{163}$ That is, after an author has asserted rights over a work, are there "enough and as good" other works or ideas out there, for others to claim? Others have critiqued the author reward argument for the practical reason that it appears to have few limiting principles. Thus, reward to authors tells us little about how much protection is enough, how much is too much, how much authors deserve. ${ }^{164}$ One could, for example, use the author reward argument to justify perpetual copyright ownership in the fruits of an author's labor. ${ }^{165}$

A number of scholars have responded to this last critique by finding ways of limiting the potential reach of natural law, thereby rendering it more useful as a practical justification for copyright law. ${ }^{166}$ One such limit is based on the recognition, even within natural law, that individuals should only be entitled to fruits of their labor that are adequately measurable and practically definable. ${ }^{167}$ Another related limit is based on the observation that creative labor is rarely the product of a

\footnotetext{
${ }^{160}$ See, e.g., Yen, supra note 57.

${ }^{161}$ See testimony by Willie Nelson, Don Henley, and others in support of term extension.

162 See Gordon, supra note 130.

163 See id. Indeed, Wendy Gordon has argued that in some cases, restrictions on the ability to build upon certain very prominent types of works might violate Locke's sufficiency proviso. See id. That is, there may be a category of works that are so prominent, important, and/or unique that they are virtually necessary in order to express oneself intelligibly about certain subjects and/or ideas. In such cases, giving an author the right to prevent uses of such essential properties may not in fact leave "enough and as good for others." That is, others might in fact be worse off than if the author had never created the work in the first place. See id. This rationale lends further support to the consideration of time in fair use analysis. The more time that passes, the greater the likelihood that certain types of works have become important in the way mentioned above.

${ }^{164}$ See Reese, supra note 159.

${ }^{165}$ Indeed, such arguments were advanced in support of perpetual copyright in England. See Walterscheid, supra note 74, at 345-46, 359 (recognizing that 'if 'reward for genius' is considered the more important rationale, then there is a pronounced tendency to lengthen the term of patents and copyrights to better assure that the 'reward' will actually occur.").

${ }^{166}$ See Yen, supra note 57; Litman, supra note 24.

${ }^{167}$ See Yen, supra note 57.
} 
single author, working alone. Rather, authors take, as the raw material of their work, ideas, thoughts, concepts, and observations from other authors that preceded them and from society more generally. ${ }^{168}$ Thus, the final work is not solely the product of the author's labor, but also of the labor of many others. As a result, the rights of the author should properly be limited, not absolute. ${ }^{169}$

These limits lend support to the idea of a limited copyright term and, for our purposes, consideration of time in determining the scope of protection. ${ }^{170}$ As mentioned above, difficulties in tracing the provenance of works can be expected to increase over time, thus imposing a limit on the ability to clearly define the entitlement. To the extent the author reward view is limited by the need to define entitlements with at least some degree of precision, this reward should wane as definitional problems increase. Moreover, this limitation recognizes that all authors generally benefit from being able to build upon the ideas of others, and that they all share an obligation of some kind to prior authors. Thus, the eventual passage of an author's work into the public domain can be seen as part of the bargain that the author strikes in creating a work that inevitably builds upon the creative labor of those who have preceded her. ${ }^{171}$ To the extent that an author herself has built upon the labor of others before her, she has a moral obligation to similarly permit those coming after her to build upon her labor. The idea is that authors have a moral obligation to help replenish the public domain. ${ }^{172}$

Again, these observations tell us little about how long to set the term. They may suggest a limit imposed by time, but do little to indicate what that limit should be. Once again, however, a precise figure isn't necessary to support the broader argument that time should matter. Once we accept the view that an author's moral claim to compensation should be limited and that a limit on the term of the copyright is an appropriate mechanism for such a limitation, it also follows that the longer a piece

\footnotetext{
${ }_{168}^{16 e e}$ Litman, supra note 24, at 1007-08.

${ }^{169}$ See Yen, supra note 57; Litman, supra note 24, at 1011. A variation of this idea, based on post-modern literary theory, suggests that authorship as a concept should have less relevance today, and that the audience also has a strong claim to providing meaning for the work. See, e.g., Lange, supra note 140; see also Peter Jaszi, Toward a Theory of Copyright: The Metamorphosis of "Authorship”, 1991 DukE L.J.I 455, 457-63. But see Ginsburg, supra note 157.

${ }^{170}$ Even those who support a more author-centric conception of copyright law were troubled by the Sonny Bono Term Extension Act, insofar as the Act appeared to focus more on rewarding copyright holders rather than the authors and their families. See Ginsburg, supra note 29, at 171; William Patry, The Failure of the American Copyright System: Protecting the Idle Rich, 72 Notre Dame L. ReV. 907 (1997); Patry, supra note 4.

${ }^{171}$ See Ginsburg, et. al., supra note 52, at 683 (2000).

${ }^{172}$ See Gordon, supra note 130. Any Rawlsean analyses of this issue? Nunziato?
} 
has been out, the weaker the author's moral claim to compensation is. As time passes, difficulties in defining the scope of the entitlement increase. Moreover, the longer the piece has been out, the greater the chance that it has contributed to the stock of ideas to which the original author owes a debt, and upon which other authors will want to build.

In addition, the continuing success of a work many years after its original creation may undercut the moral claim to reward in another way. If copyright is seen as a reward for creative labor, then we might ask to what extent the revenue generated by a work 70 years after the author's death is directly the result of such labor. Indeed, it may well be that the continued success of such a work owes less to the original labor of the author, and more to the contributions of society or the public more generally in imbuing that work with certain meanings. Again, take the case of Mickey Mouse. To what extent is the continuing success of that work due to the original creative labor of Walt Disney, the individual who first drew him? Do we really believe that the relative success of Mickey Mouse (over other cartoon characters of the time) is solely or even primarily the result of better creative choices made by Disney at the time? A strong argument exists that, the further we move from the original creative act, the more likely it is that the continuing success of the work is due to factors unrelated to the original creative labor. Thus, to this extent, we can expect the moral claim for reward to wane over time.

A closely-related, though analytically separate, line of argument focuses not so much on the need to reward authors for their creative labor, as on the need to protect certain personality interests of authors that are peculiar to creative works. This justification asserts that products of creative thought are peculiarly personal to the authors and represent an expression of the individual's self, which should be protected in certain ways from certain types of harm. Based in part on the writings of Hegel, and elaborated upon most effectively by Margaret Radin, these arguments justify aspects of copyright protection based on the personhood interests of the authors. ${ }^{173}$ Although such arguments have generally been much more influential in Continental copyright law, they have recently found expression in the U.S. through the recognition of certain moral rights in integrity and attribution for certain works of fine art. ${ }^{174}$ These new enactments are designed not so much to protect the financial interests of authors, as their interests in reputation.

These arguments also support a limited copyright term. Again, at first blush, one might think that interests in attribution and integrity should be recognized in perpetuity, if we are truly concerned about

\footnotetext{
${ }^{173}$ See Margaret Jane Radin, Property and Personhood, 34 StAn. L. ReV. 957 (1982).

${ }^{174}$ See Visual Artists Rights Act, 17 U.S.C. § 106A.
} 
protecting reputation of authors and the integrity of certain works. However, because such interests are peculiarly personal to authors, it is unclear why such an interest should survive the author's own lifetime. Certainly, an author should have a personal interest in reputation during his or her life. But after his or her death, it becomes difficult to see why such an interest should be respected. Other personal interests in the area of tort are limited to the lifetime of the individual. ${ }^{175}$ In addition, these interests can also be far more attenuated when copyright interests have been transferred, and are thus owned, not by the original author, but by corporations or other entities, as is often the case over time ${ }^{176}$. Moreover, as more and more time passes, society more generally comes to have greater and greater claims on the work, as indicated above. Thus, for example, famous works of fine art, such as Leonardo's Mona Lisa, take on a significance within society that goes well beyond the personality interest of the long-dead artist. ${ }^{177}$ Thus, even under this view, it is clear that, as more and more time passes, the interests of the author wane.

\section{Political ECONOMY ARguments}

A final set of arguments in support of the proposal can be found in pragmatic considerations relating to the manner in which copyright law is made in the United States. It is widely accepted that copyright legislation in the U.S. responds quite directly to the lobbying efforts of the copyright industries. ${ }^{178}$ It is not hard to see why. A narrow group of interests - namely the movie, music, publishing, software industries stands to benefit from expansion of intellectual property protection. They have the resources and incentives to lobby for such expansion in Congress. By contrast, consumers individually are largely indifferent to such expansions. Although they bear much of the cost of such expansions and such costs may be significant in the aggregate ${ }^{179}$, each

\footnotetext{
${ }^{175}$ See, e.g., libel law. But see right of publicity.

${ }^{176}$ See Weinreb, supra note 110, at 1246 ("Even so, once the transfer has occurred, the personality-based aspect of the author's right is substantially gone.").

${ }_{177}$ See, e.g., Marcel DuChamp, L.H.O.O.Q.

${ }^{178}$ See Jessica Litman, Copyright, Compromise, and Legislative History, 72 CORNELL L. Rev. 857 (1987). See also Jessica Litman, Digital Copyright 35 (2001); Netanel, supra note 9, at 67-70; Denicola, supra note 113, at 1684; William F. Patry, Copyright and the Legislative Process: A Personal Perspective, 14 CARdOzO ARTs \& ENT. L.J. 139, 141 (1996); Bell, supra note 41, at 786 (arguing that the Copyright Act has fallen into "statutory failure"); Merges \& Reynolds, supra note 58, at 53-54.

${ }^{179}$ But see Hatch, supra note 7 , at 728 (arguing that costs are outweighed by incentive and other benefits of extension).
} 
consumer bears only a miniscule share, spread out over time. ${ }^{180}$ Thus, as predicted under public choice theory ${ }^{181}$, consumers do not band together in sufficient numbers to oppose efforts by the copyright industries to expand protection. ${ }^{182}$ The few interested groups that do have some focus and resources - such as libraries, educational institutions - are simply outgunned by the array of countervailing interests. Moreover, to the extent that the interests of narrow, more focused groups are taken into account, they are usually granted a narrow exemption or privilege, leaving the broader expansion intact. ${ }^{183}$

The impact of this set of circumstances on the expansion of copyright protection has been extensively documented. In the substantial 1976 revision of the Act, the copyright industries were expressly invited to participate in the crafting of the Act, in part due to the complexity of the Act and the difficulty of resolving so many competing interests. ${ }^{184}$ Thus, they had a strong hand in setting the scope of protection. Moreover, the consistent expansion of the copyright term through the $1960 \mathrm{~s}$ and $70 \mathrm{~s}$, and most recently in the Sonny Bono extension act is a clear example of the political economy of copyright protection at work. ${ }^{185}$ Despite the fact that the most recent extension was opposed by many intellectual property scholars ${ }^{186}$ and many public interest groups, and despite the nearly overwhelming arguments against extension, Congress went ahead and extended the term and applied it retroactively, largely in response to heavy lobbying pressure from the copyright industries. Given the above, it is difficult to see how repeated extension of the copyright term can effectively be resisted in any way. Existing

${ }^{180}$ But see O'Rourke, supra note 15 , at 174 (suggesting that the costs may not be that great, given other doctrines such as fair use, which mitigate the impact of the extension).

${ }_{181}$ See, e.g., Maxwell L. Stearns, Public Choice and Public Law: Readings And Commentary (1997); J. Buchanan \& Gordon Tullock, The Calculus of Consent (1962); Daniel Farber \& Philip Frickey, The Jurisprudence of Public Choice, 65 TEX. L. REV. 873 (1987). See also Frank Easterbrook, The State of Madison's Vision of the State: A Public Choice Perspective, 107 HARV. L. Rev. 1328 (1994); Statute's Domains, (judges should enforce legislative deals); Jonathan Macey, Promoting Public-Regarding Legislation Through Statutory Interpretation: An Interest Group Model, 86 ColuM. L. REV. 223 (1986).

${ }^{182}$ See James Boyle, Essay, A Politics of Intellectual Property: Environmentalism for the Net?, 47 Duke L.J. 87 (1997); Boyle, Enclosure, supra note 147.

${ }^{183}$ See Lemley, supra note 74, at 533. See, e.g., DMCA, $\S \S 1201(\mathrm{~d})-(\mathrm{h}) ; 17$ U.S.C. $\S \S$ $108,110,111,119$.

${ }^{184}$ See Jessica Litman, Copyright Legislation and Technological Change, 68 Or. L. REv. 275 (1989); Litman, supra note 178; Patry, supra note 170; Robert Merges, Intellectual Property Rights and the New Institutional Economics, 53 VAND. L. REV. 1857 (2000) (suggesting possible more benign "information transmission" explaination). But see Hatch, supra note 7. Cf. Hamilton, supra note 4 (positing a more complex relationship).

185 See Gifford, supra note 45, at 385-86 (detailing efforts of Disney to secure term extension). Disney Chairperson Michael Eisner lobbied personally for the extension.

${ }^{186}$ See Statement of Copyright and Intellectual Property Law Professors, supra note 45. 
copyright holders have powerful incentives to keep petitioning Congress for both prospective and retrospective extensions of the copyright term. ${ }^{187}$ The public at large will remain largely unresponsive. ${ }^{188}$

Indeed, one of the more pernicious and underappreciated effects of the steady extension of the copyright term over the past 30 years has been to condition the public to largely accept a world in which cultural objects are owned. As noted above in the introduction, the term is currently so long that the only works passing into the public domain have been works published before the 1920s, works that, while important, have comparatively less visibility or impact on the public today. ${ }^{189}$ We have thus grown up in a world in which most of the cultural objects we interact with on a daily basis are owned. As a result, we do not by and large register losses to the public domain, since we have never truly realized its full benefits. ${ }^{190}$ Indeed, the idea of Disney not owning Mickey Mouse seems distinctly odd. ${ }^{191}$ Contrast this with the state of affairs that existed when the copyright term was only 14 years. There, the value of the public domain was much more concrete and immediate, since valuable works would soon be in the public domain. ${ }^{192}$ Or, to take another example, consider the far shorter term in patent law, where the benefit from expiring patents is not only concrete, but an essential part of the patent bargain. Thus, through the gradual extension of the copyright term, the public has been made even less sensitive to the value of the

${ }^{187}$ Nor are these incentives only recent. See, e.g., Walterscheid, supra note 74, at 327 (detailing the practice of seeking extensions to existing patent monopolies in 18th century England).

${ }^{188}$ But see Merges, supra note 58, at 2237 (highlighting some cases where opposition might arise, e.g. database protection bills).

${ }^{189}$ Notable exceptions include such public domain works as Santa Claus, the works of Shakespeare, classical music, myths and stories.

190 See Travis, supra note 30, at 831 ("The public's reversionary interest in most twentieth-century works is functionally non-existent.").

191 See Lessig, supra note 9, at 1069 ("The ordinary person believes, as Disney’s Michael Eisner does, that Mickey Mouse should be Disney's for time immemorial. The ordinary person doesn't even notice the irony of perpetual protection for Disney for Mickey, while Disney turns out Hunchback of Notre Dame (to the horror of the Victor Hugo estate), or Pocahontas, or any nubmer of stories that it can use to make new work.").

${ }^{192}$ In his Commentaries shortly after passage of the initial Copyright Act, Justice Story wrote that short terms are beneficial because they "admit the people at large, after a short interval, to the full possession and enjoyment of all writings and inventions without restraint." See 3 Joseph Story, Commentaries on the Constitution OF THE United StATES $\S 1147$ (Fred. B. Roghman \& Co. 1991) (1833). By contrast, discussions about the value of works passing into the public domain has, until recently, been much more muted. 
public domain, and accordingly, will have even less of an incentive to resist term extension efforts. ${ }^{193}$

Given that there exist structural obstacles to Congressional responsiveness to the problems of term expansion, judicial action becomes more attractive as a possible mechanism for assuring that public-regarding limits on copyright scope are imposed. ${ }^{194}$ In recognition of this, many commentators have turned to the limits in the Constitution imposed by the Copyright Clause and the First Amendment. ${ }^{195}$ However, constitutional challenges to copyright term extension have at least thus far not proven successful. It is possible that the retroactive provisions of the Act could ultimately be struck down by the Supreme Court. If so, then this would remove much if not all of the incentive that existing copyright holders would have for petitioning for extension. However, this is still at this point a somewhat remote possibility. And the case against prospective extension is even more difficult to make, since courts will be reluctant to question Congress's judgments on such an indeterminate issue as optimal copyright length. In any event, such a result would still leave largely undisturbed the already quite lengthy pre-extension term of life plus fifty years.

Thus, the proposal in this Article may provide a more practical and effective way for courts to ameliorate some of the undesirable effects of copyright expansion and inject some public-regarding values into copyright scope over time. To the extent one finds the policy justifications above persuasive, considering time in fair use may be one of the few remaining ways for such justifications to find expression. ${ }^{196}$ Courts may thus be able to adjust the scope of protection to compensate for, or at least account for, the increase in the term of protection. Moreover, courts should be far more comfortable adapting fair use in this way, since, as demonstrated below, the proposal is clearly supported by existing doctrine and requires no departure from existing practice. Indeed, it fits rather comfortably into what courts are currently doing. And unlike constitutional challenges, courts will not need to rule on the authority of congress or to second-guess its judgments about the proper length of the copyright term. Instead, courts can apply the analysis and

\footnotetext{
193 Note there are recent efforts to change this. See, e.g., Conference on the Public Domain, Duke Law School (Nov. 9-11, 2001); Boyle, Environmentalism, supra note 182; Boyle, Enclosure, supra note 147.

194 See Merges, supra note 184 at 1875 ("In this view, courts are a necessary counterweight to inevitable rent-seeking ont he part of special interests who lobby Congress.”). C $f$. Jonathan Macey, supra note 181.

195 See supra note 74. See also Merges \& Reynolds, supra note 58; Lemley, supra note 74, at 531 (describing trend); Yen, supra note 74.

${ }^{196}$ See O'Rourke, supra note 15 (suggesting that "the Bono Act provides an even clearer example of how courts can mitigate congressional errors by applying scope-defining doctrines.").
} 
inject some of these interests and values in a more case-by-case fashion, within the existing structure of copyright law. ${ }^{197}$

It may well be, of course, that the courts are no more inclined than Congress to inject public-regarding values into the scope of copyright protection. Indeed, recent expansion of copyright and general I.P. protection has not been the exclusive province of Congress. Rather, many courts have expanded the scope of intellectual property protection on a number of fronts, through interpretations of I.P. statutes. ${ }^{198}$ Although these expansions cannot be explained by imbalances in lobbying power, a number of commentators have suggested various alternative reasons for this expansion. Certainly, the expansion could simply be the result of accurate interpretation of the I.P. statutes as a substantive matter. In a number of cases, however, courts have clearly expanded upon the scope of protection provided by the literal terms of the underlying statutes, or applied the discretion they have in a systematically expansive manner. One possible explanation comes from the rhetorical appeal of arguments based on the need to protect "property rights," without adequate consideration of the potential costs of such protection, particularly in the I.P. context. ${ }^{199}$ Another possibility comes from the fact that, as in the market for legislation, the copyright industries are repeat players in copyright litigation, ${ }^{200}$ and therefore are able to better shape the law in their favor, through selective lawsuits, selective settlements, ${ }^{201}$ and their expertise as repeat players.

Be that as it may, there are reasons to believe that the proposal offered in this Article offers a better avenue for public-regarding values to be injected into the scope of protection. As mentioned above and developed in more detail below, the proposal offered in this Article does

197 See Merges, supra note 58, at 2237 ("I am only arguing that, when an imbalance is clear, courts ought to treat it as relevant. In a close case, where a statute seems close to a line drawn by the Constitution, it should be relevant that only industry groups were represented during the drafting of the statute. Not determinative; but relevant. A copyright term incapable of serving as an incentive at any plausible discount rate ...; in these and similar cases, an inquiry into the legislative process seems a relevant consideration. In a close case, that inquiry should tip the balance.")

${ }^{198}$ See, e.g., State Street Bank \& Trust v. Signature Financial Serv., 149 F.3d 1368 (Fed. Cir. 1998); AT\&T v. Excel Communications, 172 F.3d 1352 (Fed. Cir. 1999); MAI v. Peak, 991 F.2d 511 (9th Cir. 1993); eBay v. Bidder's Edge, 100 F. Supp.2d 1058 (C.D. Cal. 1999).

199 See, e.g., Mark Lemley, Book Review, Romantic Authorship and the Rhetoric of Property, 75 TEX. L. REV. 873 (1997).

200 See Glynn Lunney, The Death of Copyright: Digital Technology, Private Copying, and the Digital Millennium Copyright Act, 87 VA. L. ReV. 813, 901 (2001).

${ }^{201}$ Compare Universal City Studios v. Corley, 273 F.3d 429 (2d Cir. 2001) (suit brought against so-called computer "hackers") with Felten v. Recording Industry Association of America, 01-CV-2669 (Nov. 28, 2001) (declaratory judgment action brought by computer science professor). 
not require courts to do any more than apply standard fair use analysis, in a manner to which they are already accustomed. It does not, as will be demonstrated below, require any major change in existing law. Moreover, the equitable balancing test provided by fair use will provide courts with an easy way of injecting such values in a more incremental, case-by-case manner, rather than by adopting a binding interpretation of a statutory provision or striking down a statute entirely. Although the effect of such a change might be less immediately dramatic, it may well be easier to achieve and will have significant effects over the long run. Finally, the courts certainly provide an alternative avenue for lawmaking that is comparatively more shielded from the lobbying pressure of the copyright industries, and thus more able to respond receptively to appeals to the public interest.

\section{DOCTRINAL ARGUMENTS}

The arguments above establish that there are extremely strong reasons to consider the passage of time in determining the proper scope of copyright protection. All of the existing justifications for copyright law support the view that copyright protection should vary over time. Indeed, after consideration of the above arguments, it seems particularly odd and artificial that courts do not consider time. Given the extreme length of the current copyright term and the extent to which markets and incentives change over such a long time period, a fair use analysis that is static and fails to consider the passage of time seems highly artificial.

What follows in this part, then, is an examination of the doctrinal case for considering time. That is, given that strong policy reasons exist to consider time in copyright law, is there doctrinal support for such a consideration? The answer is a surprisingly strong yes. Indeed, the fair use defense seems tailor-made for such a consideration, and in this section I develop the doctrinal argument, based on both the text and legislative history of the Act, as well as case law. I then address a particular doctrinal argument resulting from the recent term extension.

\section{A. TeXt, Legislative History, Case LaW}

In beginning to build the doctrinal case for the proposal, it is important to note at the outset that the fair use defense was created by the courts, not by Congress. ${ }^{202}$ The 1909 Act (and all of the preceding Copyright Acts) nowhere mentioned any defense of fair use. Rather, it defined the rights of copyright owners and presumed that infringement

${ }^{202} 2$ Goldstein, supra note 5, $§ 10: 1$, at 10:1. 
followed upon violation of these enumerated rights. Yet courts, in applying the Act, created the fair use defense out of whole cloth, viewing it as necessary to support the overall purpose of the Act and to provide an outlet for concerns about the First Amendment implications of copyright law. ${ }^{203}$ Thus, the courts fashioned and developed the defense over time, permitting use of a work for various educational, critical, and other purposes, even though such uses infringed the literal terms of the statute. Congress in 1976 finally approved of this line of judicial activism and codified the defense in $\S 107$ of the most recent Copyright Act. ${ }^{204}$

Congress's codification of the defense, however, reflected the judicial origins of the defense and left the courts with broad discretion to continue to apply fair use in a flexible manner. The House Report to the 1976 Act stated:

The statement of the fair use doctrine in section 107 offers some guidance to users in determining when the principles of the doctrine apply. However, the endless variety of situations and combinations of circumstances that can rise in particular cases precludes the formulation of exact rules in the statute. The bill endorses the purpose and general scope of the judicial doctrine of fair use, but there is no disposition to freeze the doctrine in the statute, especially during a period of rapid technological change. Beyond a very broad statutory explanation of what fair use is and some of the criteria applicable to it, the courts must be free to adapt the doctrine to particular situations on a case-by-case basis. $^{205}$

Thus, Congress expressly contemplated that fair use would continue to be a flexible doctrine, which judges could freely adapt to meet changing circumstances. ${ }^{206}$

The text of the fair use defense reflects this orientation toward flexibility and adaptability, setting forth a number of nonexclusive factors that a court should consider in making the case-by-case determination of fair use:

\footnotetext{
${ }^{203}$ The earliest articulation of the fair use defense in U.S. law is generally considered to be Folsom v. Marsh, 9 F. Cas. 342 (C.C.D. Mass. 1841) (Story, J.).

${ }^{204}$ Footnote on fair use literature.

${ }^{205}$ House Report, at 26.

${ }^{206}$ See 2 Goldstein, supra note 5, §10.1.4 at 10:11; Stewart v. Abend, 495 U.S. 207, 246 (1990) (fair use doctrine "permits [and requires] courts to avoid rigid application of the copyright statute when, on occasion, it would stifle the very creativity which that law is designed to foster").
} 
$\S 107$. Limitations on exclusive rights: fair use.

Notwithstanding the provisions of sections 106 and 106A, the fair use of a copyrighted work ... for purposes such as criticism, comment, news reporting, teaching ..., scholarship, or research, is not an infringement of copyright. In determining whether the use made of a work in any particular case is a fair use the factors to be considered shall include -

(1) the purpose and character of the use, including whether such use is of a commercial nature ...;

(2) the nature of the copyrighted work;

(3) the amount and substantiality of the portion used in relation to the copyrighted work as a whole; and

(4) the effect of the use upon the potential market for or value of the copyrighted work.....

Note that the text, as suggested by the legislative history, sets forth various factors and purposes, but does not purport to make them exclusive in any way. Instead, courts are expected to continue to apply fair use in a flexible manner. ${ }^{207}$

A court could, consistent with the text of the Act, properly consider time in at least two places. First, a court could consider the passage of time under the second fair use factor, the nature of the copyrighted work. ${ }^{208}$ Courts have, in considering this factor, generally focused on whether the work was a creative (as opposed to factual) work, and whether a work was published or not. ${ }^{209}$ As a general matter, creative or unpublished works are accorded a greater degree of protection. Nothing in the text of the statute, however, would prevent a court from also considering the age of the work, since this is certainly a part of the "nature" of that work. Indeed, in some cases, the unpublished status of a work may correspond to its age, as was the case in Harper \& Row Publishers v. Nation Enterprises, which involved unauthorized publication of excerpts from an about-to-be-published biography of Gerald Ford. ${ }^{210}$ Moreover, in other cases, courts have considered other

207 This delegation of authority from Congress gives courts a significant role in determining the practical scope of copyright protection. See 2 Goldstein, supra note 5 .

${ }^{208}$ See, e.g., Note, supra note 10, at 1212 (proposing that courts deciding cases involving the re-writing of another author's copyrighted work consider time in the second fair use factor).

209 See 2 Goldstein, supra note 5, at \$10.2.2, at 10:48; Harper \& Row v. Nation Enterprises, 471 U.S. 539 (1985).

${ }^{210} 471$ U.S. 539 (1985). See also Salinger v. Random House, Inc., 630 F. Supp. 413 (S.D.N.Y. 1986) (Leval, J.). Of course this may not always be the case. See generally, 
factors in analyzing the nature of the work. ${ }^{211}$ The policy arguments above provide ample support for considering time in this factor. A court would thus consider whether a work was an old work or a newer work, and this would in turn be folded into the consideration of fair use more generally.

Second, a court could consider time independently as a separate and distinct factor. As mentioned above, it is clear from both the text of the statute and the legislative history that the factors in $\S 107$ are not exclusive. The text expressly states that the factors to be considered "shall include," and nowhere suggests that these factors are an exclusive list. Indeed, the legislative history behind the Act clearly establishes that Congress meant to give courts broad discretion to consider additional factors, not on the list. $^{212}$ A later House Report, in explaining the language in the statute, stated:

The Committee was concerned that as introduced, [the original language] might have been inadvertently construed to discourage courts from looking at additional factors. The phrase "all the above factors" is intended to encompass the terms "including" and "such as" embodied in the preamble to Section 107, terms that are defined in Section 101 of title 17 as being "illustrative and not limitative." Thus ... the courts must consider all four statutory factors, but they may, at their discretion, consider any other factors they deem relevant. ${ }^{213}$

Courts have, over the years, taken Congress up on this grant of discretion, considering various factors not included in the list. ${ }^{214}$ These

Kenneth D. Crews, Fair Use of Unpublished Works: Burdens of Proof and the Integrity of Copyright, 31 ARIz. ST. L.J. 1, 7 (1999).

211 See, e.g., Sony v. Universal City Studios, 464 U.S. 417 (1984) (offered to the public for free); Lewis Galoob Toys v. Nintendo of Am., 964 F.2d 965 (9th Cir. 1992) (underlying work already sold); out of print status [discuss in more detail].

${ }^{212}$ See 4 Melville Nimmer \& David Nimmer, Nimmer ON COPYRIGHT, § 13.05[A], at 13153 (2001) ("[T]he factors contained in Section 107 are merely by way of example, and are not an exhaustive enumeration. This means that factors other than those enumerated may prove to have a bearing upon the determination of fair use."). Harper \& Row Pub., Inc. v. Nation Enterp., 471 U.S. 539, 570 (1985); Castle Rock Enter. v. Carol Pub. Group, Inc., 150 F.3d 132, 141 (2d Cir. 1998); Sega Enterp. Ltd. v. Accolade, 997 F.2d 1510 (9th Cir. 1992); Maxtone-Graham v. Burtchaell, 803 F.2d 1253 (2d Cir. 1986), cert. den. 481 U.S. 1059 (1987).

${ }^{213}$ See H.R. Rep. No. 836, 102d Cong., 2d Sess. 9-10 (1992).

${ }^{214}$ See 2 Goldstein, supra note 5, §10.2 at 10:18; Harper \& Row v. Nation Enterp., 471 U.S. 539, 562-63 (1985); Brewer v. Hustler Magazine, 749 F.2d 527, 529 (9th Cir. 1994) ("Section 107 sets forth four nonexclusive factors"); DC Comics Inc. v. Unlimited 
additional factors have included, variously: the bad faith of the defendant (resulting in a narrower scope of fair use), ${ }^{215}$ acceptance of public funds by the author in creating the work (resulting in a broader scope of fair use), ${ }^{216}$ and industry custom ${ }^{217}$. [Develop this caselaw more]. Thus, the fair use doctrine clearly authorizes courts to consider time as a factor in fair use analysis. ${ }^{218}$ The only question is whether a court, in exercising its clearly-delegated discretion to consider time in fair use analysis, feels that such a consideration is warranted or desirable. As demonstrated in the previous part of this Article, overwhelmingly strong policy considerations support considering time as a factor in fair use analysis and indicate that considering time as a factor would greatly improve the ability of courts to establish the proper scope of fair use over time. This should ideally provide courts with ample incentive to factor this into the consideration of fair use.

Indeed, considering time as a factor in fair use would not be a dramatic departure from existing practice. As indicated above, courts already consider additional factors not mentioned in the statute. Moreover, courts occasionally consider the impact of time, if not expressly, at least implicitly because some of the mentioned factors are sometimes correlated with, or influenced by, the passage of time. ${ }^{219}$ The Supreme Court's decision in Harper \& Row is an example of this. As mentioned above, the case involved a magazine's publication of as-yetunpublished excerpts from former president Gerald Ford's biography. In that case, the relative youth of the work clearly had an impact on the fair use analysis. Moreover, the court clearly recognized that the youth of the work had an impact on the various policy justifications discussed in detail above. For example, the court expressly considered the impact on

Monkey Business, Inc., 598 F. Supp. 110, 119 n.2 (N.D. Ga. 1984) (“Section 107 does not limit a court to consideration of only the four factors enumerated in the Statute."). See generally Cohen, Fair Use in the Law of Copyright, ASCAP COPYRIGHT LAw SYMPOSIUM No. 6, 43 (1955).

${ }^{215}$ See, e.g., Atari Games Corp. v. Nintendo of Am., 975 F.2d 832, 834 (Fed. Cir. 1992); Roy Export Co. Establishment v. Columbia Broad. Sys., 503 F. Supp. 1137 (S.D.N.Y. 1980), aff'd, 672 F.2d 1095 (2d Cir.), cert. den. 459 U.S. 826 (1982); Haberman v. Hustler Magazine, 626 F. Supp. 201, 214 (D. Mass. 1986); cf. Harper \& Row v. Nation Enterprises, 471 U.S. 539 (1985).

${ }^{216}$ See, e.g., Wojnarowicz v. American Family Assn., 745 F. Supp. 130 (S.D.N.Y. 1990).

${ }^{217}$ See, e.g., Triangle Pubs. v. Knight-Ridder Newspapers, 626 F.2d 1171 (5th Cir. 1980).

${ }^{218}$ But see, Crews, supra note 210, at 7 ("Despite congressional intent to consider other factors and to keep fair use flexible for diverse and changing circumstances, most analyses and court rulings have relied extensively --if not exclusively - on four statutory factirs: Purpose, nature, amount, and effect.").

219 See O'Rourke, supra note 15, at 174 ("Moreover, at least some of these doctrines, particularly fair use, tend to be time-sensitive, allowing more use of information if relevant market indicators demonstrate that competition would be enhanced by permitting certain uses to proceed."). 
licensing revenues, from the subsequent inability of Ford's publishers to license initial magazine rights. The court also recognized the loss of control regarding the first appearance of the work on the market. Thus, courts have, in some cases, considered time, at least implicitly in the first factor.

Similarly, the fourth factor, the potential impact on the market, is a factor that might well be influenced by the passage of time. The younger the work, the greater potential there exists for an existing or potential market to be affected by a particular use. Conversely, the older the work, the less likely a market might be affected, particularly if the work is no longer being fully exploited. ${ }^{220}$ Similarly, under the influential market-failure justification of fair use $^{221}$, the degree of transactions costs can be expected to vary with the passage of time. Under this justification, certain fair uses of works can be explained as a response to market failure when the cost of seeking a license exceeds the value of the use. As a work ages, the costs of locating the copyright owner and negotiating a copyright license increase. Similarly, the younger a work, the easier it is to locate the copyright owner. Moreover, the youth of a work might also convince a court to give the copyright owner more time to find ways of reducing licensing costs for certain types of works. ${ }^{222}$ Thus, as noted above, courts have in the past considered time at least implicitly in their analysis of fair use. The proposal in this Article argues that this consideration be made explicit. ${ }^{223}$

Thus, at the end of the day, the statute, legislative history, and case law all provide ample support for a court to consider time as a factor in fair use analysis. This strong doctrinal support, combined with the extremely strong policy arguments, should provide courts with all the support they need to consider time as a factor in fair use analysis.

\footnotetext{
${ }^{220}$ See Robert Kreiss, Accessibility and Commercialization in Copyright Theory, 43 UCLA L. REV. 1, 72 (1995) (arguing for greater scope of privilege to copy out-of-print books); legislative history suggesting greater scope.

${ }^{221}$ See Wendy Gordon, Fair Use as Market Failure: A Structural and Economic Analysis of the Betamax Case and its Predecessors, 82 ColuM. L. REv. 1600 (1982).

${ }^{222}$ See Robert Merges, Contracting Into Liability Rules: Intellectual Property Rights and Collective Rights Organizations, 84 CALIF. L. REV. 1293 (1996); Robert Merges, The End of Friction? Property Rights and Contract in the "Newtonian" World of On-Line Commerce, 12 BERKELEY TECH L.J. 115 (1997).

${ }^{223}$ An alternative to the approaches described above, and one that splits the difference between current and proposed practice, would be to consider time more contextually, not as an independent element, but as a consideration that informs all of the existing elements of the fair use test. For a number of the reasons below, see infra Part IV.B, there are significant advantages to making consideration of time more explicit, and this Article makes that argument. However, if courts are reluctant to consider time expressly, at the very least, they should recognize the impact of time in consideration of the existing factors.
} 


\section{B. DEALING With SONNY BONO}

One obvious doctrinal counter-argument could be based on Congress's enactment of the Sonny Bono Copyright Term Extension Act. The argument would look something like this. Congress recently extended the term of copyright protection by an additional 20 years. In so doing, Congress expressly found that the incentive from an additional 20 years was justified for various reasons, including the increased useful life of works in the digital age and the need to harmonize U.S. copyright law with European copyright law. By taking time into account in fair use analysis and effectively reducing the scope of protection over time, courts would be acting to frustrate this legislative intent. Thus, courts cannot consistent with the recent term extension consider time as a factor in fair use analysis.

This argument is weak on a number of fronts. First, the argument finds no support as a matter of statutory interpretation. The plain text of the term extension clearly says nothing at all about fair use and what courts should consider in fair use analysis. Its very limited and focused purpose is to extend the term by an additional 20 years, and consideration of time in fair use analysis is in no way inconsistent with the plain terms of the extension. Thus, a plain meaning reading of the extension does not foreclose consideration of time. Second, there is clearly no specific intent of congress that would be frustrated by consideration of time in fair use. That is, Congress did not, in passing the extension, specifically intend that courts should refuse to consider time or freeze the scope of fair use. This is not surprising, since as noted above, courts have not considered time in their fair use analysis. Thus, Congress could not have anticipated or had any specific intention about such practice.

Third, addressing the real gist of the argument, the more general intent of Congress to extend the term would not be frustrated by interpreting fair use to incorporate consideration of time. As a general matter, it would be difficult to argue that the extension of the term should have an impact on fair use more generally. That is, Congress clearly did not intend to shrink or freeze the scope of fair use in enacting the extension act or limit the considerations available to courts under $\S 107$. For example, the extension could not be interpreted as limiting a court's ability to interpret fair use more broadly (or more narrowly) as a general matter. Indeed, this would be clearly at odds with the clear mandate from the 1976 Congress that fair use be interpreted in a flexible manner to adapt to changing conditions. Rather, Congress intended merely to extend protection, whatever the substantive scope of that protection might be, another 20 years. 
In this respect, considering time as a factor in fair use analysis does not conflict with the extension of the term, since it does not affect the duration of the copyright. Put more simply, the extension dealt with the length of copyright protection, not its scope. Authors will still be entitled to an additional 20 years of copyright term protection. However, that additional 20 years will, like any other 20 year period of the copyright term, be subject to whatever limitations courts choose to place under the fair use defense. Consideration of time is but one of many other possible factors in fair use analysis. If a court expressly deprived an author of any protection for that additional 20 year period, this would clearly be inconsistent with the intent and policy of the Act. And certainly, if this proposal aimed to accomplish the same goal, albeit not explicitly, then a strong argument could be made that the intent of Congress was being frustrated. I.e. if this proposal had the practical effect of eliminating protection or severely limiting protection for that 20 year period, this might be problematic.

However, the proposal here is far more modest. It does not deprive authors of protection for the extension period. Indeed, authors will still have a great degree of protection. ${ }^{224}$ They will still have full rights during that period to prevent copying, public distribution, public display, public performance, and the creation of derivative works. Such rights will simply, like rights during the term more generally, be subject to limitation by fair use. Nor, as developed in more detail below, is the proposal even targeted expressly at the extension term. Rather, the proposal is a change in the scope of fair use that would apply over the entire length of the copyright term and, in some cases, might result in increased protection earlier in a copyright's term. Thus, the proposal is truly a proposal aimed more at scope rather than duration, and one that is not in any way inconsistent with Congress's intent in enacting the Bono act. $^{225}$

Finally, even if such an interpretation were in some modest amount of tension with congressional intent in enacting the term extension, good reasons exist for interpreting the enactment narrowly and not extending its impact or preemptive effect beyond the literal words of the enactment itself. A number of commentators writing about theories of statutory interpretation have suggested that courts should subject statutes to narrower construction when they result from systemic or

\footnotetext{
${ }^{224}$ The Sonny Bono Act does include an exception to infringement for libraries during the extension period, "for purposes of preservation, scholarship, or research," under certain circumstances. 17 U.S.C. $\S 108$.

${ }^{225}$ See Garon, supra note 30, at 600 (suggesting that Congress either repeal the extension or modify the extension so that protection is more limited during the extension period).
} 
structural imbalances in lobbying power. ${ }^{226}$ Under this view, courts engaging in interpretation have a role in policing the legislative process, to check such imbalances and to ensure that public-regarding values are represented. As described above, the copyright term extension bears all of the hallmarks of a statute enacted largely in response to unequal lobbying power. Accordingly, under this interpretive view, the scope of the term extension should not be read more broadly than necessary. ${ }^{22}$

This view is, naturally, not uncontroversial. A number of commentators have argued that legislation represents little more than the bargain struck by competing interest groups lobbying for legislation, and the role of the courts is to enforce this bargain. ${ }^{228}$ Thus, under this view, courts should try to effectuate the intent of the parties to the agreement and refrain from any expansive interpretation of statutes that would frustrate this intent. Indeed, under this view, the injection of publicregarding values outside the legislative bargain struck by competing lobbying groups would be an illegitimate exercise of judicial power. Applied to the proposal in this Article, the argument would be that the Bono act should in fact be interpreted to bar the proposal, since the parties who lobbied for the extension, i.e. the copyright owners, clearly expected and intended for the additional 20 years of protection to be full and unaffected by the passage of time.

A lengthy discussion of this debate is beyond the scope of this Article. Suffice it to say that I find generally more persuasive the interpretive stance adopted by the commentators arguing for stricter scrutiny of statutes resulting from systematic imbalances in lobbying power. Although one must certainly be careful about distinguishing between cases where such imbalances are systematic and cases where imbalances are simply part of the regular political process, the evidence suggests that the recent extension of copyright protection is not a case that is close to the line. In any event, even under the interest-group bargain theory, there is little evidence, as already demonstrated above,

\footnotetext{
${ }^{226}$ See, e.g., Daniel Farber \& Philip Frickey, LAw And Public Choice: A CRitical INTRODUCTION 131 (1991); see also Netanel, supra note 9, at n. 278; William Eskridge, Jr., Politics Without Romance: Implications of Public Choice Theory for Statutory Interpretation, 74 VA. L. REV. 275, 303-09 (1988); William Eskridge Jr., et al., LEGISLATION AND STATUTORY INTERPRETATION 81-90 (2000); Macey, supra note 181; Cass Sunstein, Interpreting Statutes in the Regulatory State, 103 HARV. L. REV. 405, 471 (1989). The same argument has been made in support of calls for the courts to strike down such laws as unconstitutional. See Merges \& Reynolds, supra note 58, at 60.

227 See Merges, supra note 58, at 2238 (arguing that "when an imbalance [in lobbying power] is clear, courts ought to treat it as relevant" in deciding whether the resulting statute is constitutional).

228 See Einer Elhauge, Does Interest Group Theory Justify More Intrusive Judicial Review?, 101 YAlE L.J. 31, 48-59 (1991); Robert Tollison, Public Choice and Legislation, 74 VA. L. REV. 339 (1988); Easterbrook, supra note 181.
} 
that Congress had any specific or general intent regarding the scope of copyright protection and certainly such an interpretation is not found anywhere in the "text" of the bargain. Finally, as argued above, no real tension exists between Congressional intent (of whatever kind) and this proposal, since the proposal in this Article is truly a proposal dealing with the scope of copyright protection.

\section{THE PROPOSAL IN DETAIL}

Having constructed both the policy and doctrinal arguments in support of the proposal, I now turn to the specifics of the proposal. The proposal itself is easy to state: courts should consider time as a factor in fair use analysis. What remains is an elaboration of what the proposal means and what sorts of concrete results would follow from its adoption. In particular, how might copyright law be different if we adopted this proposal? As the analysis below will show, consideration of time would improve fair use analysis by permitting courts to tailor fair use more accurately in response to the justifications underlying copyright law more generally.

\section{A. SOME EXAMPLeS}

As described above, the most straightforward manner of incorporating time as a factor in fair use analysis would be to consider it as one of the many factors in fair use analysis. Thus, it would not be dispositive in and of itself. ${ }^{22}$ The fact that a work is very old or very young would not be sufficient to settle whether a use was fair. Rather, a court would still consider all of the other factors in fair use analysis. Consideration of time would simply be folded into the broader analysis. At the same time, the impact of time on fair use would not be trivial. Indeed, consideration of time would have the effect of greatly increasing the scope of fair use at the end of the copyright term, and perhaps decreasing the scope of such use at the beginning of the copyright term.

\section{Transformative Uses}

Some examples will help clarify how time might affect the scope of fair use. Take, for example, the recent dispute involving publication

\footnotetext{
${ }^{229}$ See, e.g., Note, supra note 10, at 1213 (making similar point with respect to proposal that courts consider time in deciding cases involving the re-writing of another author's copyrighted work).
} 
of the book The Wind Done Gone. ${ }^{230}$ In the Wind Done Gone, the author Alice Randall created a fictional work based on Margaret Mitchell's Gone With the Wind, ${ }^{231}$ re-telling aspects of the story from the perspective of a woman named Cyanara, the daughter of a slave living on the plantation. In so doing, Randall appropriated many characters (such as Scarlett O'Hara, Rhett Butler, Ashley Wilkes, Mammy, etc. ${ }^{232}$, plot, and major scenes from Gone With the Wind. In addition, Randall allegedly copied into portions of her book certain verbatim dialogue and descriptions from Gone With the Wind. Randall intended for the book to serve as a critique of Gone With the Wind's depiction of slavery in the Civil War era. ${ }^{233}$

Upon learning of the book, the estate of Margaret Mitchell sued Randall for copyright infringement and the district court initially ruled in favor of the estate, enjoining publication of the work. In reaching this result, the court rejected Randall's fair use argument, primarily based upon the commercial nature of the new work and the impact on the potential market for sequels or other versions of Gone With the Wind. This decision, however, was ultimately reversed on appeal, ${ }^{234}$ the appellate court holding that Randall's fair use defense was likely to succeed. $^{235}$ In applying the four fair use factors, the court held that the use was clearly transformative, as it sought to parody and critique the original, and that there was insufficient evidence to support a finding that the market for Gone With the Wind or any derivative works would be harmed by Randall's use.

Consideration of time as a factor in this case would have made the ultimate outcome easier to reach. ${ }^{236}$ A court considering time would have noted that the original Gone With the Wind was published in 1936, and was nearing the end of its copyright term. ${ }^{237}$ This means that

\footnotetext{
${ }^{230}$ Suntrust Bank v. Houghton Mifflin, 268 F.3d 1257 (11th Cir. 2001). This specific example has been developed in Note, supra note 10, at 1193 . It has been also a popular example in much recent copyright literature. Cite.

${ }^{231}$ Margaret Mitchell, Gone With THE Wind (1936).

232 These characters were in many cases re-named, although clearly with reference to the original (e.g. Rhett Butler was renamed R.B., etc.). Suntrust, 268 F.3d at 1267.

${ }^{233}$ For a similar situation involving a re-telling of Vladimir Nabokov's Lolita, see Peter Applebome, Pact Reached on U.S. Edition of "Lolita" Retelling, N.Y. TIMES, June 17, 1999, at E1.

${ }^{234}$ Suntrust Bank v. Houghton Mifflin, 268 F.3d 1257 (11th Cir. 2001).

235 The appellate court initially vacated the injunction on the grounds that it represented an unconstitutional prior restraint. Suntrust Bank. v. Houghton Mifflin Co., 252 F.3d 1165 (2001). It subsequently supplemented its initial order with a more comprehensive opinion on the substantive copyright issue.

${ }^{236}$ See Note, supra note 10

${ }^{237}$ The court in Suntrust briefly noted that Gone With the Wind was approaching the end of its copyright term, but only in mentioning that future derivative works would only be
} 
Margaret Mitchell and her estate had had more than 60 years of exclusive right to sell the work, to authorize new versions of the work, and to exploit the work through derivative works such as movies, ${ }^{238}$ sequels, ${ }^{239}$ etc. By any measure, both Mitchell and the estate have been amply compensated for the work. ${ }^{240}$ At the same time, Gone With the Wind has, over time, achieved a prominence in our culture that makes it a desirable target for re-invention and re-telling. Indeed, as the appeals court in Suntrust noted, the book is one of the best-selling works of all time, second only to the Bible. Accordingly, the scope of permissible transformative re-telling should be much greater now, more than 60 years after original publication.

Of course, consideration of time would need to be weighed along with the other fair use factors. Thus, in this case, time would be merely another factor weighing in favor of fair use, along with the transformative nature of the use. On the other hand, one could imagine a different set of facts, under which time would not be sufficient to lead to a finding of fair use. For example, say the case had involved the defendant merely selling exact, unauthorized copies of the original novel. Under such circumstances, the age would weigh in favor of fair use, but would be outweighed by the other four factors, which would all point against the use. Thus, time would not by itself by dispositive, though it would affect the analysis.

Consideration of time as a factor might also mean, conversely, more protection in the initial years of a work's life. That is, including time in fair use does not necessarily result in less overall protection for copyrighted works. Indeed, it might mean even more protection in the initial years of a work, when the value of such protection is greatest. The level of protection would only vary over time. Thus, for example, imagine the same set of facts in the Wind Done Gone, but applied to the most recent Harry Potter Novel. ${ }^{241}$ For example, say an author decides to publish his own version of Harry Potter, but from the perspective of one of the minor characters in the book. And suppose that this perspective is a critical one, highlighting certain undesirable assumptions underlying the book. Even though the facts might be nearly identical to those in the Wind Done Gone, considering time as a factor could lead a court to find no fair use. Here, the work has only been published for a couple of

protected as to their original contributions, and that elements drawn from the underlying work would pass into the public domain. Suntrust, 268 F.3d at 1275.

${ }^{238}$ See Margaret Mitchell, Gone With the Wind (1938).

239 See Alexandra Ripley, Scarlett: The Sequel to Margaret Mitchell's Gone With THE Wind (1992).

${ }^{240}$ See Note, supra note 10, at 1211-12.

${ }^{241}$ See, Note, supra note 10, at 1213 (arguing that this would be a closer case). The Harry Potter books themselves are the subject of an ongoing copyright dispute. Cite. 
years. Accordingly, the original author has not had the full time period to exploit the work commercially. Moreover, the interest in controlling derivatives is much stronger, since licensing such derivatives takes both time and effort, and only a short period of time has passed. ${ }^{242}$ However, one could expect that the exact same facts occurring 80 years from now would likely lead to a different result.

Or take another example, Mickey Mouse. In the late 1970s, Disney sued the publishers of a counter-culture comic book, titled Air Pirates, which depicted Mickey and Minnie Mouse engaging in drugsmuggling and various lascivious acts. Although the court in that case held that this constituted a parody sufficient to trigger a possible fair use defense, the court ultimately concluded that the use was not fair, based upon a weighing of the four factors. ${ }^{243}$ If the court had considered time as a factor in the fair use analysis, the result might well have been different. A court would have noted that Disney had enjoyed, by that time, more than 40 years of copyright protection for Mickey Mouse, a significant time period within which to earn a return and develop various sequels and other properties based on the original creative work. Moreover, Mickey Mouse had during that time attained a certain status and cultural significance. ${ }^{244}$ This, weighed against the various other factors, could well have been sufficient to tip the case and result in a finding for the defendants. By the same token, had the same case arisen in the 1940s, the same analysis suggested here might well have led to a different result.

Finally, take an example of a derivative, but non-critical, use. In Castle Rock Entertainment v. Carol Publishing ${ }^{245}$, the owners of the copyright in the popular television comedy Seinfeld sued an author for publishing a book called "The Seinfeld Aptitude Test," which contained trivia questions about facts from the popular television sit-com. The court held that the book was a derivative work and rejected a fair use argument based, in part, on the relatively well-established rule that, in assessing the harm to the market from a use, a court should look not only to the market for the work itself (in this case the television show), but also the market for derivative works. This consideration of the derivative market is supported by the idea that a copyright owner should naturally be given an opportunity to exploit the work through licensing or the creation of derivative works. At the same time, however, this right

${ }^{242}$ See, e.g., Castle Rock Entertainment v. Carol Publishing, 150 F.3d 132 (2d Cir. 1998).

${ }^{243}$ See Walt Disney Prods. v. Air Pirates, 581 F.2d 751 (9th Cir. 1978), cert. denied, 439 U.S. 1132 (1979).

${ }^{244}$ See Jessica Litman, Mickey Mouse Emeritus: Character Protection and the Public Domain, 11 U. Miami EnT. \& Sports L. Rev. 429, 434 (1994) ("[O]nce Mickey Mouse becomes a cultural icon, we need to be able to talk about him, sometimes irreverently."). ${ }^{245} 150$ F.3d 132 (2d Cir. 1998). 
permits copyright holders to limit efforts to build upon the work by others, raising concerns that the original author may use this right too suppress or limit certain such attempts.

Consideration of time would, again, permit courts to vary the scope of this right over time and thereby achieve a finer balance between these competing concerns. Thus, where the work is older, non-critical derivative works should have freer rein, since the copyright owner will have been given ample opportunity to develop such works on his or her own. However, where a work is relatively young, the scope of such use would be comparatively less. ${ }^{246}$ Thus, consideration of time would have lent additional support toward a finding of no fair use in the Seinfeld case. However, the exact same facts applied to an older work (e.g. a Gone With the Wind Aptitude Test) might reach a different result. [Closer example, i.e. non-derivative transformative use - e.g. movie of an old book?]

Not only do the above examples, as argued earlier, fit both doctrine and theory, they also seem quite consistent with common sense and our intuitions. Even given identical facts, it seems intuitively right that the scope of fair use for Gone With the Wind should be greater than the scope of fair use for Harry Potter. The main difference between these two examples is simply time, and what time represents with respect to many of the policy justifications underlying copyright law. ${ }^{247}$

\section{Excerpts}

Although the transformative uses discussed above perhaps present the strongest case in support of the proposal, even nontransformative uses would benefit from consideration of time. Consider, for example, the use of excerpts from copyrighted works, i.e. incorporating quotes and passages, sometimes extensively, from other works. Under the proposal, the ability of subsequent authors to incorporate excerpts from other works would affected by the age of the work. So, taking the facts from Harper \& Row, in that case, the fact that

${ }^{246}$ Note that this analysis does not say anything about whether the case was rightly decided. Only that the relative youth of the underlying work would have provided additional support to the result.

${ }^{247}$ For additional recent examples where time might have made a difference, see, e.g., Metro-Goldwyn Mayer v. American Honda Motor, 900 F. Supp. 1287 (C.D. Cal. 1995) (commercial using James Bond-like character); Dr. Seuss Enters. v. Penguin Books U.S.A., 109 F.3d 1394 (9th Cir. 1997) (use of Dr. Seuss style to retell O.J. Simpson double-murder story); Paramount Pictures Corp. v. Carol Pub. Group, 11 F. Supp.2d 329 (S.D.N.Y. 1998) (fan book called "The Joy of Trek"); Toho Co. v. William Morrow \& Co., 33 F. Supp.2d 1205, 1217 (C.D. Cal. 1998) (book called "The Official Godzilla Compendium"); Richard Feiner \& Co. v. H.R. Indus., 10 F. Supp.2d 310 (S.D.N.Y. 1998), vacated mem., 182 F.3d 901 (2d Cir. 1999) (colorized photo of Laurel and Hardy). 
the work was new would, under this proposal, have weighed against a finding of fair use. True, as already discussed above, the Court implicitly recognized the impact of time in its general fair use analysis. However, recognition of time would have been made more express under the proposal in this Article, and would have provided an easier way for the Court to reach the result it ultimately reached.

At the same time, the result might well have been different under this proposal if the case had arisen 50 years later. That is, assume that a news magazine wished to reproduce the exact same quotes, not to "scoop" the initial publication of the work, but as part of a historical analysis of some of the events described in the memoir. With these same facts, consideration of time would greatly support a finding of fair use, since much time would have passed since the original creation of the work. True, application of standard fair use analysis might also reach the same result. For example, the fourth factor in this case might well flip to favor the defendant in the case, since licensing revenues from the initial publication would not be an issue. However, licensing revenue more generally would still be an issue. Thus, it is not entirely clear that the result would be different under standard fair use analysis. Consideration of time, however, would likely lead to a different result. Either way, it would make it much easier for a court to conclude that fair use should exist under these circumstances.

\section{Personal Uses}

The examples above all involve the use of a work by a subsequent author. However, the proposal in this Article could also be applied to personal uses by consumers as well. For a large number of such cases, consideration of time may well make no difference whatsoever. For example, take the question of personal copying of television broadcasts for purposes of time-shifting, the issue raised in Sony v. Universal. The proposal in this Article suggests that the scope of fair use for such broadcasts should depend on the age of the copyrighted work. Thus, personal copying of older shows from the 1920s would be subject to greater privilege than similar copying of very recent shows. However, other factors might well counterbalance the impact of time under such circumstances. Thus, under these circumstances, factors such as the impact on the market, the nature of the use, etc. might lead courts to reach essentially the same result, whether time is considered or not.

At the same time, however, consideration of time might make a difference with respect to cases involving personal uses in the context of new technologies. Indeed, consideration of time in fair use analysis has the unexpected benefit of solving certain long-standing puzzles within 
fair use more generally. Take, for example, the issue of photocopying of journal articles. In American Geophysical Union v. Texaco, ${ }^{248}$ a number of scientific journal publishers brought suit against Texaco for its practice of systematically circulating these journals among its research scientists and permitting them to make photocopies of articles for their files. The court in American Geophysical rejected a fair use defense, pointing in particular to the availability of licenses offered by the Copyright Clearance Center, a rights-management organization.

American Geophysical points to a puzzle within the very influential market failure justification for fair use. As described above, under this justification, fair use should be permitted in cases where the costs of securing a license to engage in that use exceed the value of that use. $^{249}$ However, this justification is complicated by the potential emergence of private rights-clearance organizations that could reduce the costs of licensing. Examples of such organizations include BMI and ASCAP for music licensing and the Copyright Clearance Center for journal copies. These organizations reduce the costs of licensing such works by providing blanket licenses to organizations permitting them to engage in certain uses of works covered by those organizations and by monitoring the uses for compliance with the terms of the licensing agreements. Where such organizations exist, as in American Geophysical, the justification for fair use may be undercut, since licenses are easily available.

The puzzle arises when courts are forced to deal with fair uses involving new technologies. For example, in Sony v. Universal, the Supreme Court had to decide whether private taping of television broadcasts for later viewing constituted fair use. Under the market failure view, such taping would be strongly supported given that the cost of an individual securing a license to engage in such use exceeded the value of that use. However, since the decision was handed down only shortly after the VCR was introduced to the market, no organizations had yet arisen to issue such licenses and, as some have argued, ${ }^{250}$ the decision in Sony effectively prevented any such organizations from ever arising. At the same time, it is quite possible that such organizations would never have arisen given the economics particular to that market. Thus, a court presented with a fair use issue involving new technology is forced at the outset to make a prediction based on inadequate information that might have substantial effects on the structure of an emerging market. ${ }^{251}$

\footnotetext{
${ }^{248} 60$ F.3d 913 (2d Cir. 1994).

249 See Gordon, supra note 221.

${ }^{250}$ See Merges, Contracting, supra note 222.

251 See Richard Adelstein \& Steven Peretz, The Competition of Technologies in Markets for Ideas: Copyright and Fair Use in Evolutionary Perspective, 5 INT'L REV. L. \& ECON.
} 
One response to this puzzle is that courts should err on the side of finding no fair use, since this at least gives private institutions a chance to develop. ${ }^{252}$ A number of commentators have argued that, since a decision permitting fair use will necessarily prevent the creation of such private institutions, courts should be wary of making such a determination without more evidence that there exist structural barriers to the creation of such institutions. However, this suggestion is still lessthan-optimal, because if such institutions do not in fact develop, there may be a cost associated with foregone uses. That is, individuals will be barred from exercising certain fair uses, and no low-cost licensing mechanisms will permit them to obtain access. Moreover, courts are often not in the best position to accurately assess the potential for such institutions to develop.

A more satisfactory answer is provided by consideration of time in fair use analysis. By considering time, a court could adjust its finding of fair use depending on when the issue was presented to it. Thus, if a technology is entirely new and it is possible that private licensing schemes might develop, a court could find no fair use in order to give institutions the chance to develop such schemes. By contrast, if a technology has been in place for a long time and no such institutions or licensing schemes have developed, then a court might be more willing to consider a fair use argument, since the failure of such institutions to develop would be evidence that the economics are such that the market will not solve the transactions cost problem on its own. Note that in this case, time is being considered, not with respect to the underlying copyrighted works, but rather with respect to the technology. In any event, opening up fair use analysis to consideration of time would provide this additional benefit. ${ }^{253}$

[Other examples? Out of print books, Napster, etc.?]

\section{Summary}

The results stated above have a certain amount of intuitive appeal. That Mickey Mouse should have more protection in the initial years and less in later years seems, in some ways, appropriate, given the shifting structure of incentives and the growing claims of the public upon the work. Indeed, upon reflection, it is somewhat odd that the scope of protection for a work would, at least facially, remain essentially

209, 210-17 (1985). Another example is Lewis Galoob Toys v. Nintendo of America, 964 F.2d 965 (9th Cir. 1992).

${ }^{252}$ See Merges, Contracting, supra note 222.

${ }^{253}$ Address objections about constant revisiting with lawsuits, etc. 
unchanged over the vast time period covered by the current copyright term, only to disappear suddenly upon expiration of the copyright term. Instead of such a result, the proposal in this Article suggests that courts should take account of the passage of time in setting the proper scope of fair use. Thus, as time passes, the copyright owner's interest in a work begins to wane, while the public obtains greater use of the work. The work is, of course, still protected, and thus still retains much of its value as a piece of intellectual property. However, the scope of that protection varies across time.

Note that in all of the above cases, the ultimate policy considerations underlying the use of time as a factor might overlap or correspond with considerations underlying some of the other factors. For example, the more recent the work, the greater likelihood that uses might interfere with the market value. However, this is no objection to using time as an independent factor, since many of the existing factors already overlap. Most notably, the commercial or non-commercial nature of the work will often correspond with the impact of the work on the market. ${ }^{254}$ Thus, as with the existing factors, courts will need to be aware of the ways in which the various factors work together. At the same time, however, time captures additional considerations that may not be captured in the other factors. Moreover, it may also serve as a useful and easier-to-measure proxy for some of the other, more difficult-to-assess factors.

\section{B. OBJECTIONS}

A number of objections could be raised against the proposal in this Article. One objection is that considering time as a factor in fair use analysis will only serve to make copyright entitlements more uncertain. As a general matter, we prefer to have clear entitlements, since clarity reduces both the potential for, and the cost of, disputes. ${ }^{255}$ If entitlements are clear, parties will know what their rights are and thereby avoid infringement. And even in cases of infringement, courts will be able to resolve the issue expeditiously, where a clear rule exists. Moreover, clarity facilitates efficiency by lowering the costs of bargaining. Thus, one practical objection is that adding time to the mix merely muddies the water.

\footnotetext{
${ }^{254}$ See O'Rourke, supra note 15.

${ }^{255}$ See Cooter \& Ulen, supra note 122; Mitchell Polinsky, An InTRODUCTION TO LAw AND ECONOMICs (2d ed. 1989); Merges, Contracting, supra note 222; Carol Rose, Crystals and Mud in Property Law, 40 Stan. L. Rev. 577 (1988). But see Dan Burk, Muddy Rules for Cyberspace, 21 CARDOzO L. REV. 121 (1999).
} 
As an initial matter, consideration of time would in fact add little appreciable uncertainty beyond the existing level of uncertainty in copyright law more generally. The fair use defense is notoriously uncertain in scope, since it already involves the case-by-case balancing of four statutory factors. Indeed, fair use has famously been called "the most problematic ......."256 Moreover, the act itself expressly contemplates the consideration of additional, unspecified fair use factors. Thus, the defense is already quite uncertain in scope, and the consideration of an additional factor would add little additional uncertainty. Indeed, the uncertainty is the cost associated with the great benefit of fair use analysis, its flexibility. And in giving courts a broad degree of discretion, Congress clearly made a policy choice in favor of flexibility (despite its costs).

In addition, the actual application of the factor by itself would be relatively straightforward. Unlike many of the other factors, the content of this new factor would be absolutely clear. That is, the age of a work is a fact that can be objectively determined, and that will rarely be subject of dispute. The date Gone With the Wind was published is an established fact, easily discoverable and verifiable. This is not the case with all of the other fair use factors. For example, arguably the most important factor, the impact on the market, is notoriously difficult to quantify and, particularly when dealing with markets for derivative works, subject to significant uncertainty. Thus, the new factor has an advantage in that respect.

Moreover, even the weight of this factor is relatively straightforward, insofar as it is a relatively simple sliding scale. The older the work, the greater the scope of fair use. The consideration is essentially a binary one. Although it proceeds along a continuum, from recent to old, from more protection to less, this is no different than any of the other factors. For example, works can be anywhere on the continuum between factual and creative, commercial or non-commercial, transformative or non-transformative. Similarly the amount of the original appropriated can vary from little to much, or anywhere in between. And at least in the instance of time, the factual predicate (i.e. the number of years) is unambiguous. Thus, the application of the factor itself would not add much if any additional uncertainty.

Finally, to the extent that consideration of this factor tips the scales in many cases, as in the Wind Done Gone case, it may in fact provide a clearer and simpler way of determining the scope. That is, for older works, where the factor is particularly strong, consideration of time might well make it easier for courts to reach their ultimate decision.

${ }^{256}$ Learned Hand. See also Lloyd Weinreb, Fair Use, 4 FordHAm L. REV. 1291, 1291 (1999). 
True, in other cases, consideration of time might have the effect of making what would appear to be a clear case a closer case. The point, however, is that, at the very least, we cannot be sure ahead of time whether it would increase or decrease uncertainty. Thus, there is no indication that consideration of time would make fair use analysis more complex or indeterminate, particularly given that it is already extremely indeterminate.

A second objection is that considering time is inappropriate since it acts as a proxy for other values which should be considered expressly. For example, if time serves as a proxy for incentives, a court should look directly at incentives. Or if time serves as a proxy for increased transactions costs, we should determine the scope of such costs directly, as courts sometimes already do. Or if time serves as a proxy for the cultural significance of a work, a court should look directly at that significance. Or if time serves as a proxy for the reward to authors, we should look directly at whether the reward is sufficient. ${ }^{257}$ By considering time independently, a court risks applying the factor in cases where it may not accurately reflect the true interest that we are seeking to vindicate. For example, in the case of Mickey Mouse, it is quite clear who has the rights to that cultural property, and thus concerns about licensing costs should be minimal.

My response is that time is useful precisely because it serves as a proxy for all of the above considerations. ${ }^{258}$ Direct consideration of the interests above would in fact lead to much added complexity in fair use analysis, since assessment of the multiple factors above would be difficult and highly indeterminate. ${ }^{259}$ Whether an author deserves more compensation is not something that can easily be answered with any degree of precision. Similarly, the cultural significance of a work, although perhaps easier to determine, is fraught with the type of subjective cultural value judgments that courts in copyright cases prefer to avoid. ${ }^{260}$ As I hope to have established above, however, time serves as a very good proxy for compensation to the author, as well as other important policy justifications underlying copyright law generally. And it obviates the need to consider all of them at the same time.

\footnotetext{
${ }^{257}$ See, e.g., Note, supra note 10, at 1210-15 (proposing that courts expressly consider the amount that the author has received).

${ }^{258}$ Indeed, many of the existing fair use factors can be viewed as proxies for underlying values.

${ }^{259}$ See, e.g., Note, supra note 10, at 1215 (proposing express consideration of whether a work has achieved "iconic" status, although acknowledging that this determination may be difficult).

${ }^{260}$ See Bleistein v. Donaldson Lithographing, 188 U.S. 239 (1903). But see Alfred Yen, Copyright Opinions and Aesthetic Theory, 71 S. CAL. L. REV. 247 (1998).
} 
Of course, it is not a perfect proxy. For example, one could imagine a case where a painter toiled away in obscurity for much of his life, only to achieve fame in the last 10 years of the copyright term. Under such circumstances, time is not an accurate measure of desert or of compensation. ${ }^{261}$ Similarly, many old works may have little or no cultural significance, and thus not be desirable subjects for transformation or re-imagination. However, in many cases, time will be a good proxy, and the ease of application is sufficient to justify its application as a general rule, always subject to modification if exceptional circumstances (such as the ones described above) arise. Indeed, this is the case with many of the existing fair use factors. And in many other areas of the law, we look to more easily-measurable factors as proxies for more difficult-to-measure interests, and time in this case would be no different.

A third objection is that the proposal in this case is too vague and ill-defined to have an appreciable impact on the scope of fair use more generally. ${ }^{262}$ Under this view, time, as another factor, will not contribute measurably to fair use analysis (beyond the extent to which it may or may not already be taken into account in the other factors) or make a difference in enough cases to make it worthwhile for courts to even engage in the analysis. As I hope to have shown above, however, the added cost of considering time is quite minimal, since it is rather easy to administer. Moreover, as the examples above point out, consideration of time could in fact lead to different results in an appreciable number of cases. True, the impact of time would be felt more incrementally, as courts apply the rule. However, in many ways, this is a strength of the proposal, since it permits courts to inject such considerations in a caseby-case fashion, to which courts are more accustomed. And over the long term, the impact of the change would be substantial, insofar as it would become clear that older works are subject to a greater scope of fair use.

I expect that owners of valuable long-standing copyrights will have strong objections to the proposal in this Article. It's not hard to see why. The Disney corporation, for example, derives a tremendous amount of revenue from its copyrights in Mickey Mouse, Minnie Mouse, Donald Duck, Goofy, and the rest. The analysis in this paper suggests

\footnotetext{
${ }^{261}$ Of course, the compensation in this example would go to the author's heirs, since he or she would be long dead by this time.

${ }^{262}$ Fair use can be an easy out for those who would like to see changes in the scope of copyright protection, insofar as it leaves to the courts the task of implementing proposed changes through exercise of their discretion, and does not require too much uncomfortable specificity in detailing such changes. In this case, however, the proposal is an extremely concrete one and would modify fair use analysis in a discrete and particular way.
} 
that Mickey should be subject to greater scope of fair use. Although Disney might be upset at this prospect, the public more generally should be delighted. Mickey has already received more than 60 years of exclusive copyright protection and, on top of that, a 20-year reprieve, under the copyright term extension act. Walt Disney and his descendants have, by nearly any measure, been amply rewarded for his original creative labor. $^{263}$ No authors, witnessing a greater scope of fair use of Mickey, would be deterred from creative labor by the prospect of reduced incentives. The Disney corporation has had ample time to exploit and build upon the original cultural property. And now it's time for others to have a crack at Mickey.

\section{CONCLUSION}

This Article has argued that courts should consider time when deciding whether a use is fair. The copyright act itself expressly permits courts to consider additional factors in fair use, and overwhelmingly strong policy justifications support such a consideration. Indeed, given the current length of the copyright term, a fair use analysis that did not take some account of time seems extremely artificial. By considering time as a factor in fair use analysis, courts can preserve all of the interests supporting copyright protection in the first place while permitting a more dynamic understanding of how works are built upon later.

${ }^{263}$ See Litman, supra note 244, at 431-32. 